\title{
2 Over-expression Screen of Interferon-Stimulated Genes Identifies RARRES3 as a Restrictor 3 of Toxoplasma gondii Infection
}

4

Nicholas Rinkenberger ${ }^{a}$, Michael E. Abrams ${ }^{b}$, Sumit K. Matta ${ }^{a}$, John W. Schoggins ${ }^{b}$, Neal M. Alto ${ }^{b}$, David Sibley ${ }^{a^{*}}$

${ }^{a}$ Department of Molecular Microbiology, Washington University in St. Louis, St. Louis, Missouri, USA

${ }^{b}$ Department of Microbiology, University of Texas Southwestern, Dallas, Texas, USA

Running title: ISG screen for Toxoplasma inhibitors

*Corresponding author: sibley@wustl.edu

\section{Abstract}

Toxoplasma gondii is an important human pathogen infecting an estimated 1 in 3 people worldwide. The cytokine interferon gamma (IFN $\gamma$ ) is induced during infection and is critical for restricting $T$. gondii growth in human cells. Growth restriction is presumed to be due to the induction interferon stimulated genes (ISGs) that are upregulated to protect the host from infection. Although there are hundreds of ISGs induced by IFNץ, their individual roles in restricting parasite growth in human cells remain somewhat elusive. To address this deficiency, we screened a library of 414 IFNY induced ISGs to identify factors that impact $T$. gondii infection in human cells. In addition to IRF1, which likely acts through induction of numerous downstream genes, we identified RARRES3 as a single factor that restricts T. gondii infection by inducing premature egress of the parasite in multiple human cell lines. Overall, while we successfully identified a novel IFN $\gamma$ induced factor restricting $T$. gondii infection, the limited number of ISGs capable of restricting $T$. gondii infection when individually expressed suggests that IFNY mediated immunity to $T$. gondii infection is a complex, multifactorial process.

Key words: Intracellular parasite, egress, cell death, interferon gamma, growth restriction 
Toxoplasma gondii infection is common in humans, and while typically self-limiting in immunocompetent individuals, it can be severe in congenital toxoplasmosis and in immunodeficient individuals (1). Additionally, T. gondii is a leading cause of infectious retinochoroiditis (2). Eye disease is most prominent in Latin America and Africa with approximately one third of uveitis cases being attributed to ocular toxoplasmosis(3). Although mechanisms of immune control are well studied in the mouse, they are less well understood in humans with currently known mechanisms of restriction observed in a cell type dependent manner(4).

In response to pathogen infection, host cells express and secrete interferons (IFNs), which signal in an autocrine or paracrine manner through IFN receptors to induce factors designed to block infection. Interferons fall into three categories: type I (including IFN $\alpha$ and IFN $\beta$ ), type II (IFN $\gamma$ ), and type III (IFN $\lambda 1-4)$. In general, receptors for type I and II IFN are ubiquitously expressed whereas type III IFN sensitivity is restricted to epithelial barriers. Conventionally, IFN signaling involves the induction of interferon stimulated genes (ISGs) involved in host defense via JAK-STAT mediated signaling (5-7). Although IFN upregulates expression of many genes, induction of ISGs is only semiconserved between cell types, with many ISGs being cell type dependent (7). Variability in ISG expression is perhaps due to the induction of noncanonical IFN signaling pathways that have been observed in a cell type dependent manner $(8,9)$. To identify and study the functions of this diverse set of genes, a wide variety of approaches have been utilized including ectopic overexpression, siRNA-mediated knockdown, and more recently CRISPR-Cas9 screening approaches(7). For the purpose of our study, several previous over-expression screens have been informative: an ectopic expression-based screen of type II IFN induced genes developed by Abrams et al., and the prior screen developed by Schoggins et al., which focused on type I IFN induced genes $(10,11)$. These screens utilized a lentiviral based expression cassette to express a curated library of commonly expressed ISGs in a one gene per well format. Abrams et al., successfully used this approach to identify novel type II IFN induced genes which impact Listeria monocytogenes infection while the screen developed by Schoggins et al., has been used to identify many ISGs impacting a broad range of pathogens including both bacteria and viruses(10-13). A similar ectopic expression-based screen utilized a large cDNA library to search for enhancers of STAT1 mediated transcription in $T$. gondii infected cells and successfully identified the orphan nuclear receptor TLX as an enhancer of STAT1 mediated transcription(14).

Interferon gamma (IFNY) has been known since the 1980s to be expressed during $T$. gondii infection and to be critical for restricting infection in mice(15-17). IFN $\gamma$ mediated restriction has been attributed to the expression of a group of interferon stimulated genes (ISGs) including immunity related GTPases (IRGs) and guanylate binding proteins $(G B P s)(18,19)$. IRGs and GBPs are recruited to the parasitophorous vacuole membrane (PVM) resulting in a loss of membrane integrity and parasite death(20-22). As a defense, type I and II strains of $T$. gondii express the Ser/Thr kinase ROP18, which phosphorylates and inactivates IRG proteins to prevent PVM damage(23, 24). Additionally, increased nitric oxide production due to induction of inducible nitric oxide synthase (iNOS) has also been shown to play a role in restricting $T$. gondii infection in mice in vivo and in vitro(25-27). 
IFNY is similarly important for $T$. gondii restriction in human cells in vitro and IFN $\gamma$ expression has been shown to correlate with disease severity in vivo $(28,29)$. In contrast to the situation in mouse, the reported mechanisms underlying IFN $\gamma$ mediated $T$. gondii restriction in humans tend to be cell-type specific. However, it is important to note here that many of the studies in mice have been conducted in primary cells whereas human studies have mostly relied on immortalized cell lines. This could also be an important factor in the differences between restriction mechanisms observed in mice and humans. Humans possess one truncated IRG that likely lacks GTPase activity and only one nontruncated IRG that is not IFNy or infection inducible(30). Hence, it is unlikely IRGs play a role in human resistance to $T$. gondii infection. Although human GBP1 has been shown to restrict $T$. gondii infection, it does so in a cell type dependent manner. GBP1 restricts infection in IFN $\gamma$-treated human mesenchymal stromal cells (MSCs) and lung epithelial cells (i.e. A549 cells) but not myeloid-derived cells (i.e. HAP1 cells)(31-33). GBP1 is also implicated in an inflammasome pathway that results in host cell death in human macrophages following $T$. gondii infection (34). Additionally, GBP5 has been shown to play a role in the clearance of $T$. gondii from human macrophages in vitro, albeit in an IFN $\gamma$ independent manner (35). Humans also possess an ISG15-dependent, IFN $\gamma$ inducible, noncanonical autophagy (ATG) pathway that restricts T. gondii growth in human cervical adenocarcinoma cells (HeLa cells) and A549 cells $(36,37)$. A similar noncanonical ATG dependent pathway has been reported in human umbilical vein epithelial (HUVEC) cells, although it differs slightly in culminating in lysosome fusion(38). Finally, indoleamine 2,3dioxygenase (IDO1) has been shown in vitro to restrict $T$. gondii growth by limiting L-tryptophan availability in human fibroblasts and monocyte derived macrophages as well as in human derived cell lines of myeloid, foreskin, liver, or cervix origin (e.g. HAP1s, HFFs, Huh7s, and HeLas) but not in cells lines originating from mesenchymal stem cells, the large intestine, or the umbilical endothelium (e.g. MSCs, $\mathrm{CaCO}_{2} \mathrm{~s}$, or HUVECs)(31, 39-43).

Collectively, the previous studies examining IFN $\gamma$ mediated growth restriction in human cells support a model where different mechanisms make variable contributions in distinct lineages. However, the known pathways for restriction only cover a small fraction of the genes that are normally upregulated in different human cell types following treatment with IFNY $(7,44)$. Hence, there may be additional control mechanisms not yet defined, including either those that are lineage-specific or that operate globally in all cell types. To explore this hypothesis, we screened a library of 414 IFNY induced interferon stimulated genes (ISGs) in a one gene per well format to attempt to identify novel human factors with the ability to restrict $T$. gondii infection.

\section{Results}

To identify novel ISGs that impact $T$. gondii infection, we employed a library of 414 IFN $\gamma$ induced ISGs cloned into a lentiviral expression cassette co-expressing tagRFP, as previously described by Abrams et al. (10). To screen for ISGs that restrict $T$. gondii infection, we developed a high-throughput method to quantitatively measure infection of GFPexpressing type III strain CTG parasites using automated microscopy. CTG is a type III strain of $T$. gondii that is avirulent in mice and more susceptible to IFN $\gamma$ mediated restriction than other strains thus making it ideal for 
identifying individual ISGs which can restrict infection(45-47). A549 lung epithelial cells were infected with CTG-GFP and the size of individual parasitophorous vacuoles (PVs), the number of vacuoles per field, and the percentage of vacuoles with a size consistent with containing $\geq 8$ parasites was determined after $36 \mathrm{hr}$ of culture (Figure 1A-C). A549 cells were used as they are highly permissive to transduction with our VSV-G pseudotyped lentivirus and readily infected by T. gondii. Cells were transduced with lentivirus in a one gene per well format and challenged with CTGGFP (Figure 1D). Transduction efficiency was high for most ISGs with 86\% (357/414) of ISGs expressed in at least 50\% of the cell population and $50 \%$ of ISGs (205/414) expressed in $90 \%$ of the cell population (Supplementary file 1). Using this approach, we found three ISGs that restricted infection: IRF1, TRIM31, and RARRES3(Figure 1E, Supplementary file 1). All hits were identified as significant by a two-way ANOVA $(P<0.0001)$. Interestingly, six ISGs significantly promoted parasite growth including IL7R, IFITM1, MX1, DHX58, RNF19B, and CNDP2. For the purposes of this study, we were interested in investigating ISGs that restricted infection and did not further validate or study any ISGs that promoted parasite growth. We found it curious that IDO1 was not identified by this screen considering its significant impact on infection observed in some but not all cell lines $(31,39-43)$. There have been no previous reports as to the role of IDO1 during infection in A549s and as such we generated an IDO1 deficient A549 cell line and challenged with CTG-GFP in the presence of IFN $\gamma$. Consistent with the results of our screen, IDO1 deficiency did not impair IFN $\gamma$-mediated restriction of CTG-GFP (Figure 1F). It is worth noting here that the concentration of tryptophan used in the media for these experiments $(16 \mu \mathrm{g} / \mathrm{mL})$ was higher than what has been used previously to observe IDO1 mediated infection restriction, which may prevent IDO1 mediated depletion of tryptophan(40). However, in the present study, a much higher dose of IFN $\gamma$ was also used to induce strong ISG expression and this might be expected to overcome increased tryptophan levels. Collectively, our results suggest that IDO1 does not play a major role in the restriction of $T$. gondii in A549 cells under the experimental conditions used in this study.

\section{Validation of Screen Hits}

Cells ectopically expressing IRF1, TRIM31, and RARRES3 expanded normally and showed similar viability compared to a luciferase control when stained with the live-dead stain SYTOX green, suggesting that the overexpression of these genes is not cytotoxic (Figure 2A-B). To confirm that these genes restrict $T$. gondii infection, we ectopically expressed these genes in A549 cells and challenged with CTG-GFP for 36 or 96 h. RARRES3 and IRF1 ectopic expression resulted in a reduction in average vacuole size at $36 \mathrm{~h}$ (Figure 2C-D). At $96 \mathrm{~h}$, the total area infected per well was significantly lower for RARRES3 and IRF1 expressing cells compared to control as was the average size of infection foci (Figure 2EF). TRIM31 had no significant effect on infection in validation experiments and it was not studied further. IRF1 has a known role in amplifying IFN $\gamma$ mediated transcription, and its role relative to IFN $\gamma$ is further explored below. RARRES3 is a small, $18.2 \mathrm{kDa}$ single domain protein in the HRASLS subfamily(48). RARRES33 has been shown to inhibit immunoproteasome expression in cancer cells(49). It displays phospholipase A1/2 activity in vitro and has been shown to suppress Ras signaling and promote apoptosis(50-52). Although RARRES3 was described by a previous 
screen to be antiviral(12), it was not studied further and little is known about its involvement in immunity to other pathogens. In studies described below, we explore its role in restricting growth of intracellular T.gondii.

\section{IRF1 versus IFNy induced genes}

In mice, Irf1 deficiency has been shown to result in increased susceptibility to $T$. gondii infection (53), consistent with the secondary induction of a broad set of ISGs downstream of IFN dependent STAT-mediated gene expression(54). However, it is unknown what subset of IFN $\gamma$-induced genes are regulated by IRF1 in A549 cells. To define these two gene sets, we ectopically expressed IRF1 or luciferase control in A549 cells, treated a subset of control cells with IFN , $_{\text {, }}$ and analyzed transcriptional changes by RNA-seq. For both IFNY and IRF1, the majority of changes were due to upregulation and we focused our analysis on these genes (Figure 3A,B). We identified 160 genes upregulated by IRF1 and 380 genes upregulated by IFN $\gamma$ in A549 cells (FDR $\leq 0.05,2$ fold) (Supplementary file 2). When we compared these gene lists with the ISG library with which we challenged T. gondii infection, we found that $41.1 \%(86 / 160)$ of IFNy induced genes and 53.8\% (156/380) of IRF1 induced genes were represented by the library (Supplementary file 3). Notably, strongly induced ISGs were more commonly represented in the ISG library with $69 \%$ of the top 100 strongest induced genes by IFN $\gamma$ and $67 \%$ of those induced by IRF1 being represented (Figure 3C, Supplementary file 3). Gene ontology (GO) analysis for the lists of IRF1 and IFN $\gamma$ induced genes revealed induction of very similar processes that were grouped into IFN signaling, immune response regulation, host defense, and antigen presentation (Figure 3D-E). Interestingly, RARRES3 was strongly induced by both IRF1 and IFN $\gamma$ treatment. This is consistent with the previously reported finding that IRF1 expression strongly induces RARRES3 expression in human hepatoma and skin fibroblast derived cell lines(11).

\section{RARRES3 does not affect immune signaling}

To determine if the observed reduction in infection with RARRES3 overexpression might also be due to induction of interferon expression and downstream ISG induction, we used CRISPR/Cas9 mediated gene editing to generate a $\mathrm{STAT1}^{-/}$A549 cell line (Figure 4A-B). We ectopically expressed RARRES3 in these cells and subsequently infected with CTG-GFP parasites. The same phenotypes were observed with RARRES3 ectopic expression irrespective of the presence of STAT1, suggesting that decreased infection on over-expression of RARRES3 is not due to induction of IFNy signaling (Figure 4C-F). Interestingly, we noticed that RARRES3 ectopic expression resulted in a modest increase in the number of PVs observed at $36 \mathrm{~h}$ in wild type cells and was slightly more pronounced in STAT1 ${ }^{-1-}$ cells (Figure 2C, 4C). We further tested if ectopic expression of RARRES3 impacted NF-KB or interferon signaling by using KB-, ISRE-, and GAS-luciferase reporter cell lines. RARRES3 did not significantly impact luciferase expression for any of the reporters tested (Figure 4G-J). These findings suggest that RARRES3 does not modulate immune signaling pathways and instead plays a direct role in restricting infection.

Catalytic activity is required for infection restriction and endogenous RARRES3 can restrict infection 
As previously stated, RARRES3 displays phospholipase A1/2 activity in vitro and these enzymes belong to the H-RAS suppressor like (HRASLA) subfamily (50). Phospholipase and acyltransferase activities of HRASLS subfamily enzymes involve the temporary acylation of an active site cysteine residue(48). To determine if the catalytic activity of RARRES3 was required for restriction of infection, we generated two active site point mutants (C113A, C113S) of RARRES3. Cells ectopically expressing mutant or WT RARRES3 were subsequently challenged with CTG-GFP. Although WT RARRES3 restricted infection, neither mutant was able to do so (Figure 5A). Notably, RARRES3 C113A ectopic expression slightly promoted infection. Analysis of protein expression by western blot indicated that both mutants were strongly expressed compared to WT (Figure 5B). These data suggest that the enzymatic activity of RARRES3 is necessary for restriction of infection. To determine if endogenously expressed RARRES3 impacts infection, we next used CRISPR/Cas9 mediated gene editing to generate a RARRES3 ${ }^{-/-}$A549 cell line. Alternatively, cells were transduced with an expression cassette containing Cas9 and a previously used nontargeting sgRNA to serve as a negative control(55). RARRES3 deficiency did not alter the susceptibility of quiescent cells to infection (Figure 5C-D). However, RARRES3 deficiency partially alleviated IFNp-mediated restriction of CTG-GFP infection and this deficiency was complemented with RARRES3 ectopic expression (Figure 5C-D). As previously mentioned, RNA-seq analysis showed that RARRES3 expression was strongly induced by both IRF1 and IFN . Since RARRES3 was the only ISG identified by our screen to restrict $T$. gondii infection, we wanted to determine if the impact of IRF1 on infection was solely due to upregulation of RARRES3 expression. To test this, we ectopically expressed IRF1 or luciferase control in WT and RARRES3 $^{-/}$A549 cells and challenged them with CTG-GFP. However, loss of RARRES3 did not impact IRF1 mediated restriction of infection (Figure $\mathbf{5 E}$ ). This suggests that either IRF1 mediated infection restriction is RARRES3 independent or involves multiple factors with RARRES3 playing a redundant role in the process of restricting growth. As previously mentioned, CTG is a type III strain of $T$. gondii that is less virulent in mice and more susceptible to IFN $Y$ mediated restriction than other strains (45-47). We wanted to determine if RARRES3 also impacts other strains of $T$. gondii. To test this, we infected A549s ectopically expressing RARRES3 with GFP expressing RH88 (Type I) and Me49 (Type II). However, RARRES3 had no impact on the infection of either of these two strains (Figure 5-figure supplement 1). Differential expression or polymorphic virulence factors may explain the disparity in susceptibility to RARRES3 mediated restriction between strains $(47,56)$.

\section{RARRES3 promotes premature egress}

We subsequently revisited our previous finding that infection in RARRES3 ectopically expressing cells results in more, smaller PVs at $36 \mathrm{~h}$ than control. This result suggested to us that RARRES3 might be promoting premature egress of the parasite. To test this possibility, we infected A549 cells ectopically expressing RARRES3 with CTG-GFP parasites and measured lactate dehydrogenase (LDH) release (Figure 6A). RARRES3 ectopic expression resulted in increased LDH release in CTG-infected cells compared to control cells (Figure 6A). We next sought to differentiate if the observed LDH release was due to protein kinase G (PKG) dependent, active parasite egress or a form of induced cell death. To differentiate between these two hypotheses, we treated cells during infection with a trisubstituted pyrrole 
T. gondii protein kinase $\mathrm{G}$ inhibitor known as Compound $1(57,58)$. Compound 1 is a potent inhibitor of parasite egress and has also been shown to promote differentiation from tachyzoites to bradyzoites, significantly slowing parasite growth thus also delaying or preventing egress(59-61). Treatment with Compound 1 blocked the LDH release observed during infection and compound 1 treated cells did not stain with propidium iodide, suggesting that host cell death as measured by LDH release was due to parasite egress (Figure 6B, Figure 6-figure supplement 1A). To further confirm that RARRES3 induces premature egress, we directly measured the kinetics of CTG-GFP egress from RARRES3 or FLUC control expressing cells via time-lapse imaging of live cells by video microscopy. Parasites egressed significantly sooner in RARRES3 expressing cells compared to control (two-way ANOVA, $P<0.0001$ ), further confirming that RARRES3 induces premature parasite egress (Figure 6C, Video 1-2).

In addition to increased parasite egress, we observed a reduction in host cell number during infection in cells ectopically expressing RARRES3 compared to control at $36 \mathrm{~h}$ postinfection (Figure 6D). Similar to above, this phenotype was blocked by Compound 1 addition. A common trigger of premature egress is the induction of cell death pathways, of which there is a diversity of types controlled by different mechanisms (62-65). If induction of host cell death is the trigger for premature egress, we would expect to observe host cell death even when parasite egress is blocked. Hence, we were curious if extending this timepoint further would reveal host cell death even with blockage of parasite egress by Compound 1. However, Compound 1 addition during infection resulted in no significant increase in LDH release or propidium iodide staining even $72 \mathrm{~h}$ after infection (Figure 6E, Figure 6-figure supplement 1B). Meanwhile, in untreated, infected cultures the cell monolayer was nearly completely lysed and LDH activity was elevated in the supernatant (Figure 6E, Figure 6-figure supplement 1C). Further, we did not observe signs of death such as cell rounding, blebbing or loss of nuclear integrity prior to parasite egress during live imaging (Video 1-2). Collectively, these findings suggest that induction of cell death by RARRES3 is not the trigger for promotion of parasite egress. To further test this idea, we treated cells with a panel of established inhibitors of known cell death pathways during infection either individually or in combination as indicated (Figure 6F). These inhibitors included the pan-caspase inhibitor Z-VAD-FMK, which blocks apoptosis; the necroptosis inhibitors GSK'963, GSK'872, and necrosulfonamide (NSA), which block RIP1, RIP3, and MLKL activity respectively; and the pyroptosis inhibitor Z-YVAD-FMK, which blocks caspase 1. No single drug or combination thereof was capable of inhibiting LDH release during infection except for GSK'872, which partially prevented LDH release in both RARRES3 ectopically expressing and control cells. Overall, we conclude from these experiments that it is unlikely that over expression of RARRES3 induces cell death and therefore it must trigger premature egress by some other means.

A similar premature egress phenotype to that observed here has previously been identified in HFF cells(64). We hypothesized that RARRES3 might play a role in this process. To test this possibility, we ectopically expressed RARRES3 in HFF cells and infected with CTG-GFP parasites. RARRES3 ectopic expression was found to restrict CTG infection (Figure 7A-B). We next ablated RARRES3 expression in HFFs using CRISPR/Cas9 mediated gene editing. Loss of RARRES3 resulted in a partial reduction in IFNY-dependent cell death in RARRES3 ${ }^{-/-}$HFF cells compared to control 
cells expressing Cas9 and a nontargeting sgRNA (Figure 7C). This finding indicates that RARRES3 plays a role in premature egress but is not the only factor involved in HFF cells. In line with this finding, RARRES3 deficiency in HFF cells partially abrogated IFNY-mediated restriction of CTG-GFP infection (Figure 7D). Moreover, treatment with Compound 1 completely blocked cell death during infection, suggesting that cell death is caused by PKG dependent parasite egress (Figure 7E, Figure 6-figure supplement 1D-F). Collectively, this data suggests that RARRES3 overexpression promotes premature parasite egress independently of host cell death pathways in multiple cell lines which presumably stunts parasite growth leading to reduced infection overall.

\section{Discussion}

The major mechanisms of IFNY-mediated immunity have been shown to be conserved in multiple cell types including embryonic fibroblasts, macrophages, and astrocytes suggesting high conservation of immune mechanisms against $T$. gondii in mice(20-22, 25-27). However, the currently known restriction mechanisms in humans show dramatic differences between cell types with no common or widespread restriction mechanism being observed. On the other hand, of the hundreds of ISGs, the vast majority have never been studied in relation to $T$. gondii, leaving open the possibility of unidentified restriction mechanisms. Herein, we performed a screen of IFNY induced ISGs to identify novel mechanisms of IFNy-mediated immunity in humans. Our screen identified RARRES3 and IRF1 as ISGs restrictive to $T$. gondii infection in human cells. Further study revealed that RARRES3 induced premature egress of $T$. gondii from host cells in a cell death independent manner. Not unexpectedly, IRF1 induced genes were largely found to be a subset of those induced by IFNY, including RARRES3. These findings suggest that IRF1 works by the collective action of multiple ISGs. The relative lack of individual ISGs that are active alone also suggests that control mechanisms effective against $T$. gondii rely on complexes of multiple ISGs or cellular proteins working in concert. Hence the control of intracellular eukaryotic pathogens contrasts with that of viral pathogens, mirroring differences in their overall biological complexity.

We identified RARRES3 as an ISG promoting premature egress of type III strains of $T$. gondii in two different human cell lines. This phenotype occurs independently of triggering downstream immune signaling. A common cause of premature egress is the induction of host cell death pathways (62-64). And indeed, such a mechanism might be suggested due to the fact that RARRES3 ectopic expression has been previously shown to induce apoptosis(51). However, in our system RARRES3 ectopic expression was not found to impact cell death. Additionally, basal levels of LDH release were not increased in cells ectopically expressing RARRES3. Finally, when we blocked cell death pathways individually or in tandem, we did not see a reduction in LDH. The one exception to this pattern was the reduced release of LDH following treatment with GSK'872. We suspect this result is due to RIP3 inhibition mediated induction of apoptosis as has been demonstrated previously with GSK'872 treatment (66). Thus, following treatment with GSK' 872 it is likely that infection is hindered by host cell apoptosis and LDH release is not observed since cell membranes remain largely intact. The early egress phenotype observed here was similar to an IFN $\gamma$ dependent 
premature parasite egress observed in HFF cells that was independent of known cell death pathways(64). We found that ablation of RARRES3 expression partially prevented the IFN $\gamma$ and infection dependent cell death phenotype in HFF cells. Furthermore, we observed that LDH release was blocked via Compound 1 mediated inhibition of PKG suggesting that RARRES3 over-expression leads to parasite egress resulting in host cell lysis. Although previous studies using CDPK3 inhibition concluded that blocking egress was not sufficient to prevent cell death, our findings differ from this conclusion, possibly due to the stronger role for PKG in controlling egress(60). It is presently unclear how RARRES3 leads to premature egress, although it is possible that its phospholipase A1/A2 activity may alter cellular lipid pools that could induce premature egress consistent with the requirement for catalytic residues. As an example of the sensitivity of egress to membrane lipid constituents, increases in phosphatidic acid(67), or the activity of lipolytic lecithin: cholesterol acyltransferase(68) have been shown to trigger egress of $T$. gondii.

Although our studies define a role for RARRES3 in promoting early egress in vitro, they do not address how this outcome impacts parasite infection in vivo. Premature egress prevents further parasite growth and would reduce the maximum number of parasites reduce per round of infection while also incurring additional energy costs of reinvasion. Further, it removes the parasite from its protected intracellular niche, resulting in exposure to the extracellular environment and potential recognition by the immune system. Lastly, host cell death that accompanies premature egress is a proinflammatory event that would presumably lead to a heightened immune response (69). For these reasons, we expect that the early egress induced by RARRES3 would be protective against $T$. gondii infection in vivo. However, it is possible that rapid egress could result in faster spread to neighboring cells. It is also worth noting pre-mature expulsion by phagocytic cells has been suggested to promote dissemination of $T$. gondii and other pathogens such as Cryptococcus neoformans(70, 71). Further studies using in vivo models of infection are needed to clarify the role of RARES in control of infection.

In addition to RARRES3, we found that ectopic expression of IRF1 was sufficient to restrict $T$. gondii infection. It was not surprising to us that we identified IRF1 in this screen considering the well-known role of IRF1 in the secondary induction of ISGs and other protective factors downstream of IFN signaling(54). Mice deficient in Irf1 were previously shown to be more susceptible to $T$. gondii infection(53). However, considering the limited number of ISGs found to restrict $T$. gondii infection in our screen, we were curious as to what genes or pathways were being induced by IRF1 ectopic expression and how this compared to IFN $\gamma$ mediated gene expression in A549s. Although few genes were substantially downregulated by IRF1 expression, 160 genes were upregulated $\geq 2$ fold by IRF1 compared to 380 genes with IFN $\gamma$ treatment. IRF1 induced genes were largely a subset of those IFNץ inducible genes. Notably, this is not always the case with a significant disparity in genes being induced by IRF1 compared to IFNs being reported previously in BEAS-2B cells(72). Overall, similar processes were induced by both IRF1 and IFNY and these were related to antigen processing and presentation, host defense, and immune signaling. We observed that IRF1 and IFN $p$ both strongly induced the expression of RARRES3 which led us to question if infection restriction by IRF1 was due to the induction of RARRES3 expression. However, we found that this was not the case, suggesting that RARRES3 either 
does not play a role in IRF1 mediated restriction of $T$. gondii infection or plays a redundant role. Hence it is likely that IRF1 leads to overexpression of multiple ISGs that collectively inhibit parasite growth.

Although our study is the first to broadly screen ISGs for anti-protozoal activity, it is curious that we only identified two genes that were inhibitory to $T$. gondii infection. In contrast, similar screens challenging viruses and bacteria have commonly identified a minimum of 2-3 times this number of gene products that were restrictive to infection(10-13, 73-76). To our knowledge, a total of 30 viruses and 2 bacterial pathogens have been challenged in similar screens. It is possible that the above observation may not hold as more screens are performed on other pathogens especially intracellular bacteria or parasites. One possible explanation of this difference is that $T$. gondii separates itself from the host cytoplasm via the host derived PVM that forms a barrier to otherwise harmful ISGs in the cytosol. Another explanation is that a common mechanism of ISG activity is the manipulation or shutdown of host processes required for pathogen infection. Examples include PKR and IFIT mediated inhibition of host translation machinery, processes that directly affect viral infection (7). In contrast, $T$. gondii is a relatively autonomous intracellular pathogen with relatively limited need for host machinery for its growth and replication. Hence, the fact that so few genes were identified by this screen may reflect a secluded existence of T. gondii within the PVM and its autonomy of cellular processes relative to viral or bacterial pathogens.

Alternatively, the low number of single genes that restrict growth of $T$. gondii in A549 cells suggests that IFN $p$ dependent restriction is a complex process requiring the cooperation of multiple host factors at a time. Hence, the expression of single factors may not be sufficient to restrict infection. For example, a requirement for additional factors could explain why ISG15 was not identified by this screen as ISGylation also requires ubiquitin-like conjugation to attach to target proteins(77). ISG15 knockout was previously found to enhance $T$. gondii growth in A549 cells (36) and this was attributed to its role in the targeting of autophagy machinery to the PV during infection leading to restriction of parasite growth. Currently, over 200 genes have been found to be involved in autophagy in human cells according to the human autophagy database (HADb, http://autophagy.lu/clustering/index.html). Furthermore, coimmunoprecipitation experiments indicated that ISG15 interacts directly or indirectly with more than 240 proteins(36). Thus, although ISG15 may be necessary for autophagy mediated infection restriction as observed with knockout based studies, its individual ectopic expression may not be sufficient to induce this mechanism of infection restriction. A similar explanation can be made for GBP1 that was shown via knockout experiments to be important for restriction of $T$. gondii in A549 cells previously(33). Gbp1 recruitment to the PV and parasite clearance in mice has been shown to require the autophagy machinery(78) and the interaction of GBP1 with ATG5 has been reported in a human cell line(36). In human macrophages, the AIM2 inflammasome has been reported to induce host cell death in a GBP1 dependent manner(34). Thus, the expression of GBP1 individually may not be sufficient to restrict $T$. gondii infection. A similar argument is unlikely to explain the lack of a phenotype for IDO1, which is not thought to require any other genes for its function. However, this pathway does not seem to operate in all human cells $(31,41,42)$. Our findings demonstrate that IDO1 does not impact infection in A549s at least under the conditions 
329

330

331

332

333

334

335

336

337

338

339

340

341

342

343

344

345

346

347

348

349

350

351

used in this study. Finally, it is also possible that ISGs important for T. gondii were missed by this screen as the library used herein is not an exhaustive list of all ISGs expressed in A549 cells. Hence it is possible that other ISGs that restrict $T$. gondii infection could be identified using a more focused library or using a similar approach in a different human cell line.

Although we successfully identified a novel anti-parasitic ISG impacting $T$. gondii infection, the scarcity of ISGs identified with the screening approach used here is also of interest. Our results suggest that immunity to $T$. gondii is a complex process requiring multiple factors to impact infection. This complexity differs from other intracellular pathogens such as bacteria and viruses, where single ISGs are often sufficient to inhibit infection. As such, a future loss-of-function based screen for ISGs targeting $T$. gondii infection may reveal additional mechanisms of $T$. gondii restriction.

\section{Acknowledgements}

We thank members of the Sibley lab for helpful suggestions. Partially supported by NIH grants (R21 Al154048, R01 Al118426 to L.D.S.). The Welch Foundation (I-1704 to N.M.A.) and the National Institutes of Health (Al083359 to N.M.A.).

\section{Conflicts}

We state no conflict of interest.

\section{Data deposits}

RNASeq data generated here have been deposited to GEO with the accession number GSE181861.

\section{Methods}

\section{Key Resource Table}

\begin{tabular}{|l|l|l|l|l|}
\hline $\begin{array}{l}\text { Reagent type } \\
\text { species) or } \\
\text { resource }\end{array}$ & Designation & $\begin{array}{l}\text { Source or } \\
\text { reference }\end{array}$ & Identifiers & $\begin{array}{l}\text { Additional } \\
\text { Information }\end{array}$ \\
\hline $\begin{array}{l}\text { Cell line (Homo } \\
\text { sapiens) }\end{array}$ & A549 & ATCC & $\begin{array}{l}\text { CCL-185; } \\
\text { RRID:CVCL_0023 }\end{array}$ & \\
\hline $\begin{array}{l}\text { Cell line (Homo } \\
\text { sapiens) }\end{array}$ & 293T & ATCC & $\begin{array}{l}\text { CRL-3216; } \\
\text { RRID:CVCL_0063 }\end{array}$ & \\
\hline $\begin{array}{l}\text { Cell line (Homo } \\
\text { sapiens) }\end{array}$ & HFF & ATCC & $\begin{array}{l}\text { SCRC-1041; } \\
\text { RRID:CVCL_3285 }\end{array}$ & \\
\hline Cell line (Homo & HeLa & ATCC & CCL-2; & \\
\hline
\end{tabular}




\begin{tabular}{|c|c|c|c|c|}
\hline sapiens) & & & RRID:CVCL_0030 & \\
\hline $\begin{array}{l}\text { genetic reagent } \\
\text { (Homo sapiens) }\end{array}$ & $\begin{array}{l}\text { HeLa reporter cell } \\
\text { line expressing } \\
\text { ISRE-GLUC }\end{array}$ & PMID:31413201 & $\begin{array}{l}11 \times-I S R E-G a u s s i a \\
\text { Luciferase } \\
\text { reporter line }\end{array}$ & \\
\hline $\begin{array}{l}\text { genetic reagent } \\
\text { (Homo sapiens) }\end{array}$ & $\begin{array}{l}\text { HeLa reporter cell } \\
\text { line expressing } \\
\text { GAS-FLUC }\end{array}$ & PMID: 27091930 & $\begin{array}{l}\text { HeLa reporter cell } \\
\text { line expressing } \\
\text { GAS-FLUC }\end{array}$ & \\
\hline $\begin{array}{l}\text { genetic reagent } \\
\text { (Homo sapiens) }\end{array}$ & $\begin{array}{l}\text { RARRES3 }^{-/-} \text {Lung } \\
\text { adenocarcinoma } \\
\text { (A549) }\end{array}$ & This paper & & $\begin{array}{l}\text { See Materials and } \\
\text { Methods }\end{array}$ \\
\hline $\begin{array}{l}\text { genetic reagent } \\
\text { (Homo sapiens) }\end{array}$ & $\begin{array}{l}\text { IDO1 }^{-/-} \text {Lung } \\
\text { adenocarcinoma } \\
\text { (A549) }\end{array}$ & This paper & & $\begin{array}{l}\text { See Materials and } \\
\text { Methods }\end{array}$ \\
\hline $\begin{array}{l}\text { strain, strain } \\
\text { background } \\
\text { (Toxoplasma } \\
\text { gondii) }\end{array}$ & RH88 & ATCC & 50853 & \\
\hline $\begin{array}{l}\text { strain, strain } \\
\text { background } \\
\text { (Toxoplasma } \\
\text { gondii) }\end{array}$ & Me49 & ATCC & 50611 & \\
\hline $\begin{array}{l}\text { strain, strain } \\
\text { background } \\
\text { (Toxoplasma } \\
\text { gondii) }\end{array}$ & CTG & ATCC & 50842 & \\
\hline $\begin{array}{l}\text { genetic reagent } \\
\text { (Toxoplasma } \\
\text { gondii) }\end{array}$ & RH88-GFP & This paper & & $\begin{array}{l}\text { See Materials and } \\
\text { Methods }\end{array}$ \\
\hline $\begin{array}{l}\text { genetic reagent } \\
\text { (Toxoplasma } \\
\text { gondii) }\end{array}$ & Me49-GFP & This paper & & $\begin{array}{l}\text { See Materials and } \\
\text { Methods }\end{array}$ \\
\hline $\begin{array}{l}\text { genetic reagent } \\
\text { (Toxoplasma } \\
\text { gondii) }\end{array}$ & CTG-GFP & This paper & & $\begin{array}{l}\text { See Materials and } \\
\text { Methods }\end{array}$ \\
\hline antibody & $\begin{array}{l}\text { Anti-RFP (rabbit } \\
\text { polyclonal) }\end{array}$ & Fisher Scientific & $\begin{array}{l}\text { Cat\#: R10367; } \\
\text { RRID:AB_2315269 }\end{array}$ & $(1: 2000)$ \\
\hline antibody & $\begin{array}{l}\text { Anti-GFP (mouse } \\
\text { monoclonal) }\end{array}$ & Fisher Scientific & $\begin{array}{l}\text { Cat\#: A- } \\
\text { 11120; RRID:AB_2 } \\
21568\end{array}$ & $(1: 2000)$ \\
\hline antibody & $\begin{array}{l}\text { Anti-mouse Alexa } \\
\text { Fluor } 488 \text { (goat } \\
\text { polyclonal) }\end{array}$ & Life Technologies & $\begin{array}{l}\text { Cat\#: A-11029; } \\
\text { RRID:AB_138404 }\end{array}$ & $(1: 1000)$ \\
\hline antibody & $\begin{array}{l}\text { Anti-rabbit Alexa } \\
\text { Fluor } 568 \text { (goat } \\
\text { polyclonal) }\end{array}$ & Life Technologies & $\begin{array}{l}\text { Cat\#: A-11011; } \\
\text { RRID:AB_143157 }\end{array}$ & $(1: 1000)$ \\
\hline antibody & $\begin{array}{l}\text { Anti-rabbit Alexa } \\
\text { Fluor } 488 \text { (goat } \\
\text { polyclonal) }\end{array}$ & Invitrogen & $\begin{array}{l}\text { Cat\#: A-11034; } \\
\text { RRID:AB_2576217 }\end{array}$ & $(1: 1000)$ \\
\hline antibody & $\begin{array}{l}\text { Anti-V5 (mouse } \\
\text { monoclonal) }\end{array}$ & Invitrogen & $\begin{array}{l}\text { Cat\#: R960-25; } \\
\text { AB_2556564 }\end{array}$ & $(1: 5000)$ \\
\hline antibody & Anti-mouse & LI-COR & Cat\#: 926-68070; & $(1: 5000)$ \\
\hline
\end{tabular}




\begin{tabular}{|c|c|c|c|c|}
\hline & $\begin{array}{l}\text { 680RD (goat } \\
\text { polyclonal) }\end{array}$ & Biotechnology & $\begin{array}{l}\text { RRID:AB_1095658 } \\
8\end{array}$ & \\
\hline antibody & $\begin{array}{l}\text { Anti-rabbit } \\
800 \mathrm{CW} \\
\text { (goat polyclonal) }\end{array}$ & $\begin{array}{l}\text { LI-COR } \\
\text { Biotechnology }\end{array}$ & $\begin{array}{l}\text { Cat\#: 926-32211; } \\
\text { RRID:AB_621843 }\end{array}$ & $(1: 5000)$ \\
\hline antibody & $\begin{array}{l}\text { Anti-actin (mouse } \\
\text { monoclonal) }\end{array}$ & Sigma-Aldrich & $\begin{array}{l}\text { Cat\#: MAB1501; } \\
\text { RRID:AB_2223041 }\end{array}$ & $(1: 5000)$ \\
\hline antibody & $\begin{array}{l}\text { Anti-IDO1 (rabbit } \\
\text { monoclonal) }\end{array}$ & Cell Signaling Tech & $\begin{array}{l}\text { Cat\#: 86630S; } \\
\text { RRID:AB_2636818 }\end{array}$ & $(1: 1000)$ \\
\hline antibody & $\begin{array}{l}\text { Anti-IRF1 D5E4 } \\
\text { (rabbit } \\
\text { monoclonal) }\end{array}$ & Cell Signaling Tech & $\begin{array}{l}\text { Cat\#: 8478S; } \\
\text { RRID:AB_1094910 } \\
8\end{array}$ & $(1: 500)$ \\
\hline $\begin{array}{l}\text { chemical } \\
\text { compound, drug }\end{array}$ & $\begin{array}{l}\text { Necrosulfonamide } \\
\text {; NSA }\end{array}$ & $\begin{array}{l}\text { Tocris } \\
\text { Biotechnology }\end{array}$ & Cat\#: 5025 & $(10 \mu \mathrm{M})$ \\
\hline $\begin{array}{l}\text { chemical } \\
\text { compound, drug }\end{array}$ & GSK'872 & Selleck Chemicals & Cat\#: S8465 & $(5 \mu \mathrm{M}))$ \\
\hline $\begin{array}{l}\text { chemical } \\
\text { compound, drug }\end{array}$ & Z-YVAD-FMK & Sigma-Aldrich & Cat\#: 218746 & $(10 \mu \mathrm{M})$ \\
\hline $\begin{array}{l}\text { chemical } \\
\text { compound, drug }\end{array}$ & Z-VAD-FMK & R\&D Systems & Cat\#: fmk001 & $(50 \mu \mathrm{M})$ \\
\hline $\begin{array}{l}\text { chemical } \\
\text { compound, drug }\end{array}$ & GSK'963 & Selleck Chemicals & Cat\#: S8642 & $(1 \mu \mathrm{M})$ \\
\hline $\begin{array}{l}\text { chemical } \\
\text { compound, drug }\end{array}$ & Compound 1 & MedChemExpress & Cat\#: HY-101525 & $(5 \mu \mathrm{M})$ \\
\hline $\begin{array}{l}\text { chemical } \\
\text { compound, drug }\end{array}$ & $\begin{array}{l}\text { Hoechst stain; } \\
\text { Hoechst } 33342\end{array}$ & Invitrogen & Cat\#: H3570 & $(1 \mu \mathrm{g} / \mathrm{mL})$ \\
\hline $\begin{array}{l}\text { chemical } \\
\text { compound, drug }\end{array}$ & SYTOX Green & Invitrogen & Cat\#: S7020 & $(5 \mu \mathrm{M})$ \\
\hline $\begin{array}{l}\text { chemical } \\
\text { compound, drug }\end{array}$ & $\begin{array}{l}\text { XtremeGene9 } \\
\text { DNA Transfection } \\
\text { Reagent }\end{array}$ & Roche & Cat\#: XTG9-RO & \\
\hline $\begin{array}{l}\text { recombinant DNA } \\
\text { reagent }\end{array}$ & $\begin{array}{l}\text { pHAGE NFkB-TA- } \\
\text { LUC-UBC-GFP-W } \\
\text { (plasmid) }\end{array}$ & Addgene & 49343 & \\
\hline $\begin{array}{l}\text { recombinant DNA } \\
\text { reagent }\end{array}$ & $\begin{array}{l}\text { plentiCRISPRv2 } \\
\text { (plasmid) }\end{array}$ & Addgene & 52961 & \\
\hline $\begin{array}{l}\text { recombinant DNA } \\
\text { reagent }\end{array}$ & $\begin{array}{l}\text { pLenti-Cas9-GFP } \\
\text { (plasmid) }\end{array}$ & Addgene & 86145 & \\
\hline $\begin{array}{l}\text { recombinant DNA } \\
\text { reagent }\end{array}$ & $\begin{array}{l}\text { pTRIP.RARRES3 } \\
\text { (plasmid) }\end{array}$ & PMID: 21478870 & $\begin{array}{l}\text { pTRIP.CMV.IVSb.R } \\
\text { ARRES3.ires.TagR } \\
\text { FP }\end{array}$ & \\
\hline $\begin{array}{l}\text { recombinant DNA } \\
\text { reagent }\end{array}$ & $\begin{array}{l}\text { pTRIP.V5- } \\
\text { RARRES3 WT } \\
\text { (plasmid) }\end{array}$ & This paper & & $\begin{array}{l}\text { See Materials and } \\
\text { Methods }\end{array}$ \\
\hline $\begin{array}{l}\text { recombinant DNA } \\
\text { reagent }\end{array}$ & $\begin{array}{l}\text { PTRIP.V5- } \\
\text { RARRES3 C113A } \\
\text { (plasmid) }\end{array}$ & This paper & & $\begin{array}{l}\text { See Materials and } \\
\text { Methods }\end{array}$ \\
\hline $\begin{array}{l}\text { recombinant DNA } \\
\text { reagent }\end{array}$ & $\begin{array}{l}\text { pTRIP.V5- } \\
\text { RARRES3 C113S } \\
\text { (plasmid) }\end{array}$ & This paper & & $\begin{array}{l}\text { See Materials and } \\
\text { Methods }\end{array}$ \\
\hline recombinant DNA & pDONR221 & Invitrogen & Cat\#: 12536017 & \\
\hline
\end{tabular}




\begin{tabular}{|c|c|c|c|c|}
\hline reagent & (plasmid) & & & \\
\hline $\begin{array}{l}\text { recombinant DNA } \\
\text { reagent }\end{array}$ & $\begin{array}{l}\text { pTRIP.FLUC } \\
\text { (plasmid) }\end{array}$ & PMID: 21478870 & $\begin{array}{l}\text { pTRIP.CMV.IVSb.F } \\
\text { LUC.ires.TagRFP }\end{array}$ & \\
\hline $\begin{array}{l}\text { recombinant DNA } \\
\text { reagent }\end{array}$ & $\begin{array}{l}\text { pTRIP.IRF1 } \\
\text { (plasmid) }\end{array}$ & PMID: 21478870 & $\begin{array}{l}\text { pTRIP.CMV.IVSb.I } \\
\text { RF1.ires.TagRFP }\end{array}$ & \\
\hline $\begin{array}{l}\text { recombinant DNA } \\
\text { reagent }\end{array}$ & $\begin{array}{l}\text { PTRIP.GBP2 } \\
\text { (plasmid) }\end{array}$ & PMID: 21478870 & $\begin{array}{l}\text { pTRIP.CMV.IVSb.G } \\
\text { BP2.ires.TagRFP }\end{array}$ & \\
\hline $\begin{array}{l}\text { recombinant DNA } \\
\text { reagent }\end{array}$ & pVSVg (plasmid) & PMID: 21478870 & $\begin{array}{l}\text { Plasmid } \\
\text { expressing the } \\
\text { vesicular } \\
\text { stomatitis virus } \\
\text { glycoprotein } \\
\text { (VSVg) }\end{array}$ & \\
\hline $\begin{array}{l}\text { recombinant DNA } \\
\text { reagent }\end{array}$ & $\begin{array}{l}\text { pGag-pol } \\
\text { (plasmid) }\end{array}$ & PMID: 21478870 & $\begin{array}{l}\text { Plasmid } \\
\text { expressing HIV } \\
\text { gag-pol }\end{array}$ & \\
\hline $\begin{array}{l}\text { recombinant DNA } \\
\text { reagent }\end{array}$ & $\begin{array}{l}\text { pGRA1.GFP.GRA2. } \\
\text { DHFR (plasmid) }\end{array}$ & This paper & & $\begin{array}{l}\text { See Materials and } \\
\text { Methods }\end{array}$ \\
\hline $\begin{array}{l}\text { commercial assay } \\
\text { or kit }\end{array}$ & $\begin{array}{l}\text { CyQuant LDH } \\
\text { Cytotoxicity Assay } \\
\text { Kit }\end{array}$ & Invitrogen & Cat\#: C20300 & \\
\hline $\begin{array}{l}\text { commercial assay } \\
\text { or kit }\end{array}$ & $\begin{array}{l}\text { Luciferase cell } \\
\text { culture lysis } \\
\text { reagent }(5 X)\end{array}$ & Promega & Cat\#: E1531 & \\
\hline $\begin{array}{l}\text { commercial assay } \\
\text { or kit }\end{array}$ & $\begin{array}{l}\text { Luciferase Assay } \\
\text { System }\end{array}$ & Promega & Cat\#: E1500 & $\begin{array}{l}\text { For firefly } \\
\text { luciferase }\end{array}$ \\
\hline $\begin{array}{l}\text { commercial assay } \\
\text { or kit }\end{array}$ & $\begin{array}{l}\text { Pierce Gaussia } \\
\text { Luciferase Glow } \\
\text { Assay Kit }\end{array}$ & Thermo Scientific & Cat\#: 16160 & $\begin{array}{l}\text { For Gaussia } \\
\text { luciferase }\end{array}$ \\
\hline $\begin{array}{l}\text { peptide, } \\
\text { recombinant } \\
\text { protein }\end{array}$ & $\begin{array}{l}\text { Q5 High Fidelity } \\
\text { DNA Polymerase }\end{array}$ & NEB & Cat\#: M0491 & $\begin{array}{l}\text { Recombinant } \\
\text { fragment and } \\
\text { plasmid } \\
\text { amplification }\end{array}$ \\
\hline $\begin{array}{l}\text { peptide, } \\
\text { recombinant } \\
\text { protein }\end{array}$ & $\begin{array}{l}\text { PrimeSTAR GXL } \\
\text { DNA Polymerase }\end{array}$ & $\begin{array}{l}\text { Tocris } \\
\text { Biotechnology }\end{array}$ & Cat\#: R050 & $\begin{array}{l}\text { Genomic DNA } \\
\text { amplification }\end{array}$ \\
\hline $\begin{array}{l}\text { peptide, } \\
\text { recombinant } \\
\text { protein }\end{array}$ & BsmBl-v2 & NEB & Cat\#: R0739 & \\
\hline $\begin{array}{l}\text { peptide, } \\
\text { recombinant } \\
\text { protein }\end{array}$ & BP Clonase II & ThermoFisher & Cat\#: 11789-020 & \\
\hline $\begin{array}{l}\text { peptide, } \\
\text { recombinant } \\
\text { protein }\end{array}$ & LR Clonase II & ThermoFisher & Cat\#: 11791-020 & \\
\hline $\begin{array}{l}\text { software, } \\
\text { algorithm }\end{array}$ & CellProfiler & BROAD Institute & $\begin{array}{l}\text { RRID: } \\
\text { SCR_007358 }\end{array}$ & Version 3.1 .9 \\
\hline $\begin{array}{l}\text { software, } \\
\text { algorithm }\end{array}$ & GraphPad Prism & GraphPad & $\begin{array}{l}\text { RRID: } \\
\text { SCR_002798 }\end{array}$ & Version 3.1 .2 \\
\hline $\begin{array}{l}\text { software, } \\
\text { algorithm }\end{array}$ & ImageJ & $\begin{array}{l}\text { National Institutes } \\
\text { of Health }\end{array}$ & $\begin{array}{l}\text { RRID: } \\
\text { SCR_003070 }\end{array}$ & Version $1.53 \mathrm{f} 51$ \\
\hline
\end{tabular}


352

353 software, algorithm
RRID: SCR 013672

\section{Version 2.5}

Cell lines and Parasites

HeLa adenocarcinoma, A549 lung carcinoma (ATCC \# CCL-185), HFF foreskin fibroblast (ATCC \# SCRC-1041), and human embryonic kidney-derived 293T cells (ATCC \# CRL-3216) were grown in DMEM supplemented with 10\% FBS, $10 \mathrm{mM}$ HEPES ( $\mathrm{pH}$ 7.5), $2 \mathrm{mM} \mathrm{L-glutamine,} \mathrm{and} 10 \mu \mathrm{g} / \mathrm{mL}$ gentamicin. Cells were grown at $37^{\circ} \mathrm{C}$ with $5 \% \mathrm{CO}_{2}$. Toxoplasma gondii strains RH88 (Type I), Me49 (Type II), and CTG (Type III) expressing GFP were generated via random insertion of pGRA1.GFP.GRA2.DHFR after electroporation as described previously (79). Clonal populations expressing GFP were generated via limiting dilution. T. gondii lines were passaged as described previously in HFFs grown under the conditions listed above(80). Parasite and host cell lines were confirmed to be negative for mycoplasma using an e-Myco plus kit (Intron Biotechnology).

Plasmids and Cloning

The plasmids TRIP.RARRES3 and control constructs were kindly provided by Neal Alto and John Schoggins. Briefly, the TRIP plasmid encodes an expression cassette flanked by lentiviral LTRs. Expression of a bicistronic transcript including tagRFP and a gene of interest is driven by a CMV promoter. The gene of interest and tagRFP are translated independently via an internal ribosome entry site. Cas9 resistant RARRES3 was generated from the WT TRIP.RARRES3 construct by overlap extension PCR using Q5 high fidelity DNA polyermase (NEB). N-terminally V5 tagged WT, C113A and C113S RARRES3 were generated from WT by overlap extension PCR. Fragments were cloned into pDONR221 using BP Clonase II (ThermoFisher) and subsequently cloned into pTRIP using LR Clonase II (ThermoFisher) according to the manufacturer's protocol. For CRISPR/Cas9 experiments, RARRES3 and nontargeting guides were cloned into plentiCRISPRv2 (Addgene plasmid \#52961)(81). Primers for the above cloning are listed in Supplementary file 4. For IDO1, an IDO1 targeting sgRNA was cloned into pLenti-Cas9-GFP (Addgene plasmid \#86145). Briefly, pLenti-Cas9-GFP was digested with BsmBI (New England Biolabs). Primers listed in Supplementary file 4 were annealed and ligated into the digested plasmid using T4 ligase (New England Biolabs). For the generation of pGRA1.GFP.GRA2.DHFR, an expression cassette consisting of the GRA1 5' UTR (M26007.1, nucleotides 4-615) driving the expression of GFP (MN114103.1, coding sequence) flanked by the GRA2 3' UTR (XM_002366354.2, nucleotides 997-1114) was cloned into pHL931 along with DHFR (XM_002367211.2, coding sequence) expressed from its native promoter and flanked by its 3' UTR (L08489.1).

Lentivirus Production and Cell Line Generation

TRIP lentiviruses were produced as previously described(82). Lentiviruses derived from Lenti-Cas9-GFP, lentiCRISPRv2 and HAGE NFkB-TA-LUC-UBC-GFP-W(83) were produced similarly. Briefly, 293T cells were seeded at $4 \mathrm{x}$ 
383

384

385

$10^{5}$ cells per well into 6 -well plates. Cells were transfected with $1 \mu \mathrm{g}$ pTRIP, pLenti-Cas9-GFP, plentiCRISPRv2 or pHAGE NFkB-TA-LUC-UBC-GFP-W, $0.2 \mu \mathrm{g}$ plasmid expressing VSVg, and $0.8 \mu \mathrm{g}$ plasmid expressing HIV-1 gag-pol using X-tremeGENE 9 (Sigma). Media was changed $6 \mathrm{~h}$ later and lentivirus containing culture supernatants were collected at 48 and $72 \mathrm{~h}$ post-transfection. Pooled supernatants were clarified by centrifugation at $800 \times \mathrm{g}$ for 5 min. Polybrene and HEPES were added to a final concentration of $4 \mu \mathrm{g} / \mathrm{mL}$ and $35 \mathrm{mM}$ respectively. Lentivirus was stored at $-80^{\circ} \mathrm{C}$ until use.

For lentivirus transductions, cells were seeded at $7 \times 10^{4}$ cells per well in 24 well plates. The next day, media was changed to DMEM supplemented with $4 \mu \mathrm{g} / \mathrm{mL}$ polybrene, 3\% FBS, $35 \mathrm{mM}$ HEPES, $2 \mathrm{mM}$ glutamine, and 10 $\mu \mathrm{g} / \mathrm{mL}$ gentamicin. Cells were transduced by spinoculation at $800 \times \mathrm{g}, 45 \mathrm{~min}, 37^{\circ} \mathrm{C}$. For the ISG screen, media was changed $6 \mathrm{~h}$ later to normal growth medium. Cells were replated at $48 \mathrm{~h}$ post-transduction for subsequent experimentation.

For knockout cell line generation, cells were transduced with lentiCRISPRv2 or pLenti-Cas9-GFP containing the appropriate sgRNA for Cas9 targeting as above. For lentiCRISPRv2, cells were selected for at least two weeks in growth media containing $4 \mu \mathrm{g} / \mathrm{mL}$ puromycin before experimentation. For IDO ${ }^{-1}$, STAT1 $^{-1-}$ and RARRES3 ${ }^{-/}$A549 cell lines, cells were transduced with a single lentivirus and clonal cell lineages were established through limiting dilution. For HFFs, a heterogenous bulk population RARRES3 knockout cell line was generated by transducing at a tissue culture infectious dose of $90 \%\left(\mathrm{TCID}_{90}\right)$ with two different lentiCRISPRv2 based lentiviruses expressing separate RARRES3 targeting sgRNAs. Nontargeting control cell lines were generated for use as a control in all experiments involving RARRES3 ${ }^{-\%}$ cells. Here, cells were transduced with a single lentiCRISPRv2 based lentivirus containing a single nontargeting guide. For RARRES3 and STAT1, editing was confirmed by PCR amplifying targeted loci using primers listed in Supplementary file 4 and PrimeSTAR GXL DNA polymerase (Tocris) followed by Sanger sequencing. Editing efficiency was quantitated using Synthego ICE analysis (https://ice.synthego.com/\#/). For single cell clones, $>90 \%$ editing was verified. For HFF bulk population knockout of RARRES3, $68 \%$ editing of sequenced alleles was observed. For STAT1, editing was further confirmed functionally via testing the sensitivity of cells to IFN treatment as determined by IRF1 induction. For IDO1, editing was confirmed via loss of protein expression observed by western blot.

Infections

A549 and HeLa cells were seeded at $1.5 \times 10^{4}$ in 96 well plates $24 \mathrm{~h}$ prior to infection. HFFs were seeded at $2 \times 10^{4}$ in 96 well plates $24 \mathrm{~h}$ prior to infection. Cells were infected with parasites diluted in $200 \mu \mathrm{L}$ normal growth medium for $1 \mathrm{~h}$ at $37^{\circ} \mathrm{C}$. Media was subsequently changed to $300 \mu \mathrm{L}$ normal growth medium. For single life cycle infections (typically indicated as $36 \mathrm{~h}$ infections), an MOI of 1 was used. For focus forming assay (typically indicated as $96 \mathrm{~h}$ infections), an $\mathrm{MOI}$ of 0.03 was used. For LDH assays, media was changed to $200 \mu \mathrm{L}$ normal growth medium. For experiments involving IFN $\gamma$, cells were pretreated with or without IFN $\gamma$ diluted in normal growth medium as indicated 
for $24 \mathrm{~h}$ prior to infection. For infections involving cell death inhibitors or compound 1, drugs were added during the media change after the $1 \mathrm{~h}$ infection period. For imaging-based experiments, cells were fixed in $4 \%$ formaldehyde for 10 min after infection and washed with PBS before subsequent experimentation.

Drugs

Stocks of the cell death inhibitors Z-VAD-FMK (R\&D Systems), GSK'963 (Selleck Chemicals), GSK'872 (Selleck Chemicals), NSA (Tocris), and Z-YVAD-FMK (Sigma) as well as Compound 1 (obtained from MERCK \& CO., Inc.) were prepared in DMSO. For use, the drugs were diluted in normal growth medium to the following working concentrations: Z-VAD-FMK (50 $\mu \mathrm{M})$, GSK'963 $(1 \mu \mathrm{M})$, GSK'872 $(5 \mu \mathrm{M})$, NSA (10 $\mu \mathrm{M})$, Z-YVAD-FMK $(10 \mu M)$, Compound $1(5 \mu \mathrm{M})$. A DMSO control was included in experiments involving these drugs with a final DMSO concentration of $1 \%$.

LDH Assays

LDH assays were performed with the CyQuant LDH Cytotoxicity Assay Kit (Invitrogen) according to the manufacturer's protocol. Briefly, A549 or HFF cells split in 96-well plates were infected for $1 \mathrm{~h}$ as described above with CTG-GFP at an $\mathrm{MOI}$ of 40 or 15 respectively and subsequently treated with drugs as indicated. After 36 or $72 \mathrm{~h}, 20 \mu \mathrm{L}$ of $10 \mathrm{X}$ lysis buffer or PBS was added to each well and incubated at $37^{\circ} \mathrm{C}$ for $30 \mathrm{~min}$. Afterwards, $50 \mu \mathrm{L}$ of cell supernatant was mixed with $50 \mu \mathrm{L}$ of assay buffer and substrate for $30 \mathrm{~min}$ at room temperature. The reaction was stopped with $50 \mu \mathrm{L}$ stop solution and absorbance was measured at $490 \mathrm{~nm}$.

Luciferase Assays

Previously generated HeLa cells expressing GAS-FLUC, GFP-FLUC, or ISRE-GLUC reporters were transduced with TRIP.RARRES3 or TRIP.FLUC lentivirus as described above(39, 84). For kB-LUC, HeLa cells were additionally transduced with HAGE NFkB-TA-LUC-UBC-GFP-W lentivirus. After $48 \mathrm{~h}$, cells were split into 96 well plates at $1.5 \times 10^{4}$ cells/well. Cells were treated with or without $100 \mathrm{U} / \mathrm{mL}$ IFN $\beta$ or IFN $\gamma$ as indicated for $24 \mathrm{~h}$ and subsequently infected as indicated with CTG-GFP at an MOI of 2 for $24 \mathrm{~h}$. For firefly luciferase assays, cells were lysed in $50 \mu \mathrm{L}$ of $1 \mathrm{X}$ Luciferase Cell Culture Lysis Buffer (Promega). For Gaussia luciferase assays, supernatant was collected. Luciferase assays were conducted using Pierce Gaussia Luciferase Glow Assay Kit (Thermo Scientific) or Luciferase Assay System kit (Promega) according to the manufacturer's protocol.

Next Generation RNA-Sequencing Sample Preparation and Analysis

A549 cells transduced with TRIP.IRF1 or TRIP.FLUC derived lentivirus were split at $3.5 \times 10^{6}$ into $100 \mathrm{~mm}$ dishes. After $24 \mathrm{~h}$, cells were treated with or without IFNy at $1000 \mathrm{U} / \mathrm{mL}$ for an additional $12 \mathrm{~h}$ before harvest with RLT buffer. RNA was isolated with a Qiagen RNeasy mini kit according to the manufacturer's protocol. Prior to sequencing, RNA quality was determined on an Agilent Bioanalyzer to have a RIN > 8.0. Libraries prepared from samples were analyzed 
447

448

449

450

451

452

453

454

455

456

457

458

459

460

461

462

463

464

465

466

467

468

469

470

471

472

473

474

475

476

477

478

479

with an Illumina NovaSeq 6000 S4 generating a minimum of $3 \times 10^{7}$ reads per sample. Data was analyzed with Partek Flow software. Prior to alignment, $5 \mathrm{bp}$ were trimmed from the $5^{\prime}$ end of transcripts. Only fragments $\geq 25 \mathrm{bp}$ in length were considered for alignment. Alignment was conducted with the STAR aligner and differential expression analysis was conducted using GSA analysis with recommended settings. Genes were characterized here as induced by IFNy or IRF1 if they induced gene expression $\geq 2$ fold with an FDR $<0.05$. Gene lists were compared using GeneVenn (http://genevenn.sourceforge.net/index.htm). For GO analysis, gene lists were analyzed with the PANTHER classification system using the GO biological process complete dataset $(85,86)$. Statistical significance was determined with Fisher's exact test using the Bonferroni correction for multiple testing. Only processes containing at least 25 total genes with a $p$-value $\leq 0.05$ were considered.

Immunofluorescence and Imaging

Samples were fixed in $4 \%$ formaldehyde for $10 \mathrm{~min}$ at room temperature. Wash buffer (WB) consisted of $1 \%$ FBS, 1\% normal goat serum (NGS), and 0.02\% Saponin in PBS. Samples were blocked for 30 min with PBS containing 5\% FBS, 5\% NGS, and 0.02\% Saponin. Samples were incubated with 1:2000 anti-RFP antibody (Invitrogen) and 1:2000 anti-GFP (Invitrogen) in WB overnight, washed 4 times in WB for 5 min each, and probed with 1:1000 goat antimouse Alexa Fluor 488 (Life Technologies) and 1:1000 goat anti-rabbit Alexa Fluor 568 (Life Technologies) in WB for 1 h. For IRF1 staining, 1:500 anti-IRF1 primary antibody (Cell Signaling Technology) and 1:1000 anti-rabbit Alexa Fluor 488 secondary antibody (Life Technologies) were used instead. Samples were washed 3 times with WB and nuclei were stained for 5 min with Hoechst 33342 (Life Technologies) in WB. Samples were imaged with a Cytation 3 imager (BioTek) and images were analyzed in CellProfiler v3.1.9.

For live imaging experiments, cells were imaged starting $2 \mathrm{~h}$ postinfection every $15 \mathrm{~min}$ for $48 \mathrm{~h}$ at $37^{\circ} \mathrm{C}$ under $5 \%$ $\mathrm{CO}_{2}$. Live imaging was conducted with a Zeiss Observer Z1 inverted microscope (Zeiss) using a Colibri 7 LED light source (Zeiss), ORCA-ER digital camera (Hamamatsu Photonics), Plan-Neofluar 10X (NA 0.3) objective (Zeiss), and ZEN Blue image acquisition software (v2.5). Following acquisition, channel bleed-through was subtracted from GFP channel images and images were contrast enhanced using ImageJ (v1.53f51).

Western Blotting

A549 cells were split at $2.5 \times 10^{5}$ cells per well into 6-well plates in standard growth medium. The following day, media was changed to standard growth medium supplemented with or without $1000 \mathrm{U} / \mathrm{mL}$ IFNץ. After $24 \mathrm{~h}$, cells were washed with PBS, trypsinized with $0.05 \%$ trypsin, and spun down at $200 \times \mathrm{g}$ for $5 \mathrm{~min}$. Cell pellets were washed once with PBS and lysed with CelLytic M (Millipore) supplemented with $20 \mathrm{mM} \mathrm{DTT}$ and $125 \mathrm{U} / \mathrm{mL}$ benzonase (Millipore). Samples were incubated at room temperature for $20 \mathrm{~min}$, run on a 10\%, 37.5:1 polyacrylamide gel, and transferred to nitrocellulose membranes. Membranes were blocked with $0.1 \%$ Tween-20 PBS-T containing 5\% bovine serum albumin (BSA) for 30 min. Membranes were incubated with 1:1000 rabbit antiIDO1 (Cell Signaling), 1:5000 mouse anti-V5 (Invitrogen), or 1:5000 mouse anti-actin (Sigma) in 5\% BSA PBS-T for $1 \mathrm{~h}$, 
washed 4 times with PBS-T for 3 min each, incubated with 1:5000 goat anti-mouse 680RD (LI-COR) and 1:5000 goat anti-rabbit 800CW (LI-COR) in 5\% BSA PBS-T for 30 min, washed 4 times in PBS-T for 3 min each, and washed 2 times in PBS. Membranes were imaged with a LI-COR Odyssey scanner.

Statistical Analysis

For most datasets including those normalized to control, statistical significance was determined with a twoway ANOVA and Tukey's honestly significant difference post-hoc test conducted on raw data prior to normalization and considered variance between experimental replicates and variance between experimental conditions. For LDH and luciferase reporter experiments, statistical significance was determined after normalization and considered variance between experimental replicates and variance between experimental conditions. For experiments in Figure $2 \mathrm{~A}$ and $2 \mathrm{~B}$, statistical significance was determined using a Brown-Forsythe and Welch ANOVA. Specifically for datasets not normalized to control with only two conditions, a Mann-Whitney $U$ test was used to determined statistical significance. All statistical analyses were conducted using GraphPad Prism (v3.1.2). The term 'technical replicate' refers to separate samples derived from the same original source within the same experiment (i.e. wells of a plate) processed on the same day. The term 'biological replicate' refers to separate experiments conducted on different dates with different samples.

\section{References}

1. Furtado JM, Smith JR, Belfort R, Jr., Gattey D, Winthrop KL. 2011. Toxoplasmosis: a global threat. Journal of global infectious diseases 3:281-284.

2. Weiss LM, Dubey JP. 2009. Toxoplasmosis: A history of clinical observations. International journal for parasitology 39:895-901.

3. Furtado JM, Winthrop KL, Butler NJ, Smith JR. 2013. Ocular toxoplasmosis I: parasitology, epidemiology and public health. Clinical \& Experimental Ophthalmology 41:82-94.

4. Fisch D, Clough B, Frickel E-M. 2019. Human immunity to Toxoplasma gondii. PLoS pathogens 15:e1008097e1008097.

5. $\quad$ Alspach E, Lussier DM, Schreiber RD. 2019. Interferon $\gamma$ and Its Important Roles in Promoting and Inhibiting Spontaneous and Therapeutic Cancer Immunity. Cold Spring Harbor perspectives in biology 11:a028480.

6. Lazear HM, Schoggins JW, Diamond MS. 2019. Shared and Distinct Functions of Type I and Type III Interferons. Immunity 50:907-923.

7. Schoggins JW. 2019. Interferon-Stimulated Genes: What Do They All Do? Annual Review of Virology 6:567584.

8. van Boxel-Dezaire AHH, Stark GR. 2007. Cell Type-Specific Signaling in Response to Interferon- - , p 119-154. In Pitha PM (ed), Interferon: The 50th Anniversary doi:10.1007/978-3-540-71329-6_7. Springer Berlin Heidelberg, Berlin, Heidelberg.

9. van Boxel-Dezaire AHH, Rani MRS, Stark GR. 2006. Complex Modulation of Cell Type-Specific Signaling in Response to Type I Interferons. Immunity 25:361-372. 
10. Abrams ME, Johnson KA, Perelman SS, Zhang L-s, Endapally S, Mar KB, Thompson BM, McDonald JG, Schoggins JW, Radhakrishnan A, Alto NM. 2020. Oxysterols provide innate immunity to bacterial infection by mobilizing cell surface accessible cholesterol. Nature Microbiology 5:929-942.

11. Schoggins JW, Wilson SJ, Panis M, Murphy MY, Jones CT, Bieniasz P, Rice CM. 2011. A diverse range of gene products are effectors of the type I interferon antiviral response. Nature 472:481-5.

12. Schoggins JW, MacDuff DA, Imanaka N, Gainey MD, Shrestha B, Eitson JL, Mar KB, Richardson RB, Ratushny AV, Litvak V, Dabelic R, Manicassamy B, Aitchison JD, Aderem A, Elliott RM, García-Sastre A, Racaniello V, Snijder EJ, Yokoyama WM, Diamond MS, Virgin HW, Rice CM. 2014. Pan-viral specificity of IFN-induced genes reveals new roles for cGAS in innate immunity. Nature 505:691-5.

13. Perelman SS, Abrams ME, Eitson JL, Chen D, Jimenez A, Mettlen M, Schoggins JW, Alto NM. 2016. Cell-Based Screen Identifies Human Interferon-Stimulated Regulators of Listeria monocytogenes Infection. PLoS Pathog 12:e1006102.

14. Beiting DP, Hidano S, Baggs JE, Geskes JM, Fang Q, Wherry EJ, Hunter CA, Roos DS, Cherry S. 2015. The Orphan Nuclear Receptor TLX Is an Enhancer of STAT1-Mediated Transcription and Immunity to Toxoplasma gondii. PLOS Biology 13:e1002200.

15. Suzuki Y, Orellana MA, Schreiber RD, Remington JS. 1988. Interferon-gamma: the major mediator of resistance against Toxoplasma gondii. Science 240:516-8.

16. McCabe RE, Luft BJ, Remington JS. 1984. Effect of murine interferon gamma on murine toxoplasmosis. J Infect Dis 150:961-2.

17. Shirahata T, Shimizu K. 1980. Production and properties of immune interferon from spleen cell cultures of Toxoplasma-infected mice. Microbiology and immunology 24:1109-1120.

18. Gazzinelli RT, Mendonça-Neto R, Lilue J, Howard J, Sher A. 2014. Innate resistance against Toxoplasma gondii: an evolutionary tale of mice, cats, and men. Cell host \& microbe 15:132-138.

19. MacMicking JD. 2012. Interferon-inducible effector mechanisms in cell-autonomous immunity. Nat Rev Immunol 12:367-82.

20. Ling YM, Shaw MH, Ayala C, Coppens I, Taylor GA, Ferguson DJP, Yap GS. 2006. Vacuolar and plasma membrane stripping and autophagic elimination of Toxoplasma gondii in primed effector macrophages. The Journal of experimental medicine 203:2063-2071.

21. Martens S, Parvanova I, Zerrahn J, Griffiths G, Schell G, Reichmann G, Howard JC. 2005. Disruption of Toxoplasma gondii parasitophorous vacuoles by the mouse p47-resistance GTPases. PLoS Pathog 1:e24.

22. Yamamoto $M$, Okuyama M, Ma Ji S, Kimura T, Kamiyama N, Saiga H, Ohshima J, Sasai M, Kayama H, Okamoto T, Huang David CS, Soldati-Favre D, Horie K, Takeda J, Takeda K. 2012. A Cluster of Interferon- $\gamma$-Inducible p65 GTPases Plays a Critical Role in Host Defense against Toxoplasma gondii. Immunity 37:302-313.

23. Hunter CA, Sibley LD. 2012. Modulation of innate immunity by Toxoplasma gondii virulence effectors. Nature reviews Microbiology 10:766-778.

24. Mukhopadhyay D, Arranz-Solís D, Saeij JPJ. 2020. Influence of the Host and Parasite Strain on the Immune Response During Toxoplasma Infection. Frontiers in cellular and infection microbiology 10:580425-580425.

25. Khan IA, Schwartzman JD, Matsuura T, Kasper LH. 1997. A dichotomous role for nitric oxide during acute Toxoplasma gondii infection in mice. Proc Natl Acad Sci U S A 94:13955-60.

26. Adams LB, Hibbs JB, Taintor RR, Krahenbuhl JL. 1990. Microbiostatic effect of murine-activated macrophages for Toxoplasma gondii. Role for synthesis of inorganic nitrogen oxides from L-arginine. The Journal of Immunology 144:2725.

27. Meisel R, Brockers S, Heseler K, Degistirici Ö, Bülle H, Woite C, Stuhlsatz S, Schwippert W, Jäger M, Sorg R, Henschler R, Seissler J, Dilloo D, Däubener W. 2011. Human but not murine multipotent mesenchymal stromal cells exhibit broad-spectrum antimicrobial effector function mediated by indoleamine 2,3dioxygenase. Leukemia 25:648-654.

28. Pfefferkorn ER, Eckel M, Rebhun S. 1986. Interferon-gamma suppresses the growth of Toxoplasma gondii in human fibroblasts through starvation for tryptophan. Mol Biochem Parasitol 20:215-24.

29. Meira CS, Pereira-Chioccola VL, Vidal JE, de Mattos CCB, Motoie G, Costa-Silva TA, Gava R, Frederico FB, de Mattos LC, Toxoplasma G. 2014. Cerebral and ocular toxoplasmosis related with IFN- $\gamma$, TNF- $\alpha$, and IL-10 levels. Frontiers in microbiology 5:492-492. 
30. Bekpen C, Hunn JP, Rohde C, Parvanova I, Guethlein L, Dunn DM, Glowalla E, Leptin M, Howard JC. 2005. The interferon-inducible p47 (IRG) GTPases in vertebrates: loss of the cell autonomous resistance mechanism in the human lineage. Genome biology 6:R92-R92.

31. Qin A, Lai D-H, Liu Q, Huang W, Wu Y-P, Chen X, Yan S, Xia H, Hide G, Lun Z-R, Ayala FJ, Xiang AP. 2017. Guanylate-binding protein 1 (GBP1) contributes to the immunity of human mesenchymal stromal cells against Toxoplasma gondii. Proceedings of the National Academy of Sciences of the United States of America 114:1365-1370.

32. Ohshima J, Lee Y, Sasai M, Saitoh T, Su Ma J, Kamiyama N, Matsuura Y, Pann-Ghill S, Hayashi M, Ebisu S, Takeda K, Akira S, Yamamoto M. 2014. Role of mouse and human autophagy proteins in IFN-gamma-induced cell-autonomous responses against Toxoplasma gondii. J Immunol 192:3328-35.

33. Johnston AC, Piro A, Clough B, Siew M, Virreira Winter S, Coers J, Frickel E-M. 2016. Human GBP1 does not localize to pathogen vacuoles but restricts Toxoplasma gondii. Cellular microbiology 18:1056-1064.

34. Fisch D, Bando H, Clough B, Hornung V, Yamamoto M, Shenoy AR, Frickel EM. 2019. Human GBP1 is a microbe-specific gatekeeper of macrophage apoptosis and pyroptosis. Embo $\mathrm{j}$ doi:10.15252/embj.2018100926.

35. Matta SK, Patten K, Wang Q, Kim BH, MacMicking JD, Sibley LD. 2018. NADPH Oxidase and Guanylate Binding Protein 5 Restrict Survival of Avirulent Type III Strains of Toxoplasma gondii in Naive Macrophages. mBio 9.

36. Bhushan J, Radke JB, Perng YC, McAllaster M, Lenschow DJ, Virgin HW, Sibley LD. 2020. ISG15 Connects Autophagy and IFN- $\gamma$-Dependent Control of Toxoplasma gondii Infection in Human Cells. mBio 11.

37. Selleck EM, Orchard RC, Lassen KG, Beatty WL, Xavier RJ, Levine B, Virgin HW, Sibley LD. 2015. A Noncanonical Autophagy Pathway Restricts Toxoplasma gondii Growth in a Strain-Specific Manner in IFNgamma-Activated Human Cells. MBio 6:e01157-15.

38. Clough B, Wright JD, Pereira PM, Hirst EM, Johnston AC, Henriques R, Frickel EM. 2016. K63-Linked Ubiquitination Targets Toxoplasma gondii for Endo-lysosomal Destruction in IFNY-Stimulated Human Cells. PLoS Pathog 12:e1006027.

39. Bando H, Sakaguchi N, Lee Y, Pradipta A, Ma JS, Tanaka S, Lai D-H, Liu J, Lun Z-R, Nishikawa Y, Sasai M, Yamamoto M. 2018. Toxoplasma Effector TgIST Targets Host IDO1 to Antagonize the IFN- $\gamma$-Induced Antiparasitic Response in Human Cells. Frontiers in immunology 9:2073-2073.

40. Pfefferkorn ER. 1984. Interferon gamma blocks the growth of Toxoplasma gondii in human fibroblasts by inducing the host cells to degrade tryptophan. Proc Natl Acad Sci U S A 81:908-12.

41. Woodman JP, Dimier IH, Bout DT. 1991. Human endothelial cells are activated by IFN-gamma to inhibit Toxoplasma gondii replication. Inhibition is due to a different mechanism from that existing in mouse macrophages and human fibroblasts. The Journal of Immunology 147:2019.

42. Dimier IH, Bout DT. 1997. Inhibition of Toxoplasma gondii replication in IFN-gamma-activated human intestinal epithelial cells. Immunol Cell Biol 75:511-4.

43. Schmitz JL, Carlin JM, Borden EC, Byrne GI. 1989. Beta interferon inhibits Toxoplasma gondii growth in human monocyte-derived macrophages. Infect Immun 57:3254-6.

44. Rusinova I, Forster S, Yu S, Kannan A, Masse M, Cumming H, Chapman R, Hertzog PJ. 2013. INTERFEROME v2.0: an updated database of annotated interferon-regulated genes. Nucleic Acids Research 41:D1040D1046.

45. Khaminets A, Hunn JP, Könen-Waisman S, Zhao YO, Preukschat D, Coers J, Boyle JP, Ong YC, Boothroyd JC, Reichmann G, Howard JC. 2010. Coordinated loading of IRG resistance GTPases on to the Toxoplasma gondii parasitophorous vacuole. Cell Microbiol 12:939-61.

46. Boothroyd JC, Grigg ME. 2002. Population biology of Toxoplasma gondii and its relevance to human infection: do different strains cause different disease? Current Opinion in Microbiology 5:438-442.

47. Saeij JPJ, Boyle JP, Coller S, Taylor S, Sibley LD, Brooke-Powell ET, Ajioka JW, Boothroyd JC. 2006. Polymorphic secreted kinases are key virulence factors in toxoplasmosis. Science (New York, NY) 314:1780-1783.

48. Mardian EB, Bradley RM, Duncan RE. 2015. The HRASLS (PLA/AT) subfamily of enzymes. J Biomed Sci 22:99.

49. Anderson AM, Kalimutho M, Harten S, Nanayakkara DM, Khanna KK, Ragan MA. 2017. The metastasis suppressor RARRES3 as an endogenous inhibitor of the immunoproteasome expression in breast cancer cells. Scientific Reports 7:39873. 
50. Uyama T, Jin X-H, Tsuboi K, Tonai T, Ueda N. 2009. Characterization of the human tumor suppressors TIG3 and HRASLS2 as phospholipid-metabolizing enzymes. Biochimica et Biophysica Acta (BBA) - Molecular and Cell Biology of Lipids 1791:1114-1124.

51. Tsai F-M, Shyu R-Y, Jiang S-Y. 2007. RIG1 suppresses Ras activation and induces cellular apoptosis at the Golgi apparatus. Cellular Signalling 19:989-999.

52. Han B-G, Cho J-W, Cho Y-D, Kim S-Y, Yoon H-J, Song HK, Cheong H-K, Jeon Y-H, Lee D-k, Lee S, Lee BI. 2010. Expression, purification and biochemical characterization of the $\mathrm{N}$-terminal regions of human TIG3 and HRASLS3 proteins. Protein Expression and Purification 71:103-107.

53. Khan IA, Matsuura T, Fonseka S, Kasper LH. 1996. Production of nitric oxide (NO) is not essential for protection against acute Toxoplasma gondii infection in IRF-1-/- mice. The Journal of Immunology 156:636.

54. Feng H, Zhang Y-B, Gui J-F, Lemon SM, Yamane D. 2021. Interferon regulatory factor 1 (IRF1) and antipathogen innate immune responses. PLOS Pathogens 17:e1009220.

55. Doench JG, Fusi N, Sullender M, Hegde M, Vaimberg EW, Donovan KF, Smith I, Tothova Z, Wilen C, Orchard R, Virgin HW, Listgarten J, Root DE. 2016. Optimized sgRNA design to maximize activity and minimize off-target effects of CRISPR-Cas9. Nat Biotechnol 34:184-191.

56. Rosowski EE, Lu D, Julien L, Rodda L, Gaiser RA, Jensen KDC, Saeij JPJ. 2011. Strain-specific activation of the NF-kappaB pathway by GRA15, a novel Toxoplasma gondii dense granule protein. The Journal of experimental medicine 208:195-212.

57. Gurnett AM, Liberator PA, Dulski PM, Salowe SP, Donald RG, Anderson JW, Wiltsie J, Diaz CA, Harris G, Chang B, Darkin-Rattray SJ, Nare B, Crumley T, Blum PS, Misura AS, Tamas T, Sardana MK, Yuan J, Biftu T, Schmatz DM. 2002. Purification and molecular characterization of cGMP-dependent protein kinase from Apicomplexan parasites. A novel chemotherapeutic target. J Biol Chem 277:15913-22.

58. Donald RGK, Zhong T, Wiersma H, Nare B, Yao D, Lee A, Allocco J, Liberator PA. 2006. Anticoccidial kinase inhibitors: Identification of protein kinase targets secondary to cGMP-dependent protein kinase. Molecular and Biochemical Parasitology 149:86-98.

59. Nare B, Allocco JJ, Liberator PA, Donald RG. 2002. Evaluation of a cyclic GMP-dependent protein kinase inhibitor in treatment of murine toxoplasmosis: gamma interferon is required for efficacy. Antimicrob Agents Chemother 46:300-7.

60. Lourido S, Tang K, Sibley LD. 2012. Distinct signalling pathways control Toxoplasma egress and host-cell invasion. The EMBO journal 31:4524-4534.

61. Radke JR, Donald RG, Eibs A, Jerome ME, Behnke MS, Liberator P, White MW. 2006. Changes in the expression of human cell division autoantigen-1 influence Toxoplasma gondii growth and development. PLoS pathogens 2:e105-e105.

62. Yao Y, Liu M, Ren C, Shen J, Ji Y. 2017. Exogenous tumor necrosis factor-alpha could induce egress of Toxoplasma gondii from human foreskin fibroblast cells. Parasite (Paris, France) 24:45-45.

63. Persson EK, Agnarson AM, Lambert H, Hitziger N, Yagita H, Chambers BJ, Barragan A, Grandien A. 2007. Death Receptor Ligation or Exposure to Perforin Trigger Rapid Egress of the Intracellular Parasite Toxoplasma gondii. The Journal of Immunology 179:8357.

64. Niedelman W, Sprokholt JK, Clough B, Frickel E-M, Saeij JPJ. 2013. Cell death of gamma interferon-stimulated human fibroblasts upon Toxoplasma gondii infection induces early parasite egress and limits parasite replication. Infection and immunity 81:4341-4349.

65. Rosenberg A, Sibley LD. 2021. Toxoplasma gondii secreted effectors co-opt host repressor complexes to inhibit necroptosis. Cell Host Microbe 29:1186-1198.e8.

66. Tenev T, Bianchi K, Darding M, Broemer M, Langlais C, Wallberg F, Zachariou A, Lopez J, MacFarlane M, Cain K, Meier P. 2011. The Ripoptosome, a Signaling Platform that Assembles in Response to Genotoxic Stress and Loss of IAPs. Molecular Cell 43:432-448.

67. Bisio H, Lunghi M, Brochet M, Soldati-Favre D. 2019. Phosphatidic acid governs natural egress in Toxoplasma gondii via a guanylate cyclase receptor platform. Nature Microbiology 4:420-428.

68. Pszenny V, Ehrenman K, Romano JD, Kennard A, Schultz A, Roos DS, Grigg ME, Carruthers VB, Coppens I. 2016. A Lipolytic Lecithin:Cholesterol Acyltransferase Secreted by Toxoplasma Facilitates Parasite Replication and Egress. J Biol Chem 291:3725-46.

69. Rock KL, Kono H. 2008. The inflammatory response to cell death. Annual review of pathology 3:99-126. 
671

672

673

674

675

676

677

678

679

680

681

682

683

684

685

686

687

688

689

690

691

692

693

694

695

696

697

698

699

700

701

702

703

704

705

706

707

708

709

710

711

70. Seoane PI, May RC. 2020. Vomocytosis: What we know so far. 22:e13145.

71. Drewry LL, Sibley LD. 2019. The hitchhiker's guide to parasite dissemination. 21:e13070.

72. Panda D, Gjinaj E, Bachu M, Squire E, Novatt H, Ozato K, Rabin RL. 2019. IRF1 Maintains Optimal Constitutive Expression of Antiviral Genes and Regulates the Early Antiviral Response. 10.

73. Dittmann M, Hoffmann H-H, Scull Margaret A, Gilmore Rachel H, Bell Kierstin L, Ciancanelli M, Wilson Sam J, Crotta S, Yu Y, Flatley B, Xiao Jing W, Casanova J-L, Wack A, Bieniasz Paul D, Rice Charles M. 2015. A Serpin Shapes the Extracellular Environment to Prevent Influenza A Virus Maturation. Cell 160:631-643.

74. Kuroda M, Halfmann PJ, Hill-Batorski L, Ozawa M, Lopes TJS, Neumann G, Schoggins JW, Rice CM, Kawaoka Y. 2020. Identification of interferon-stimulated genes that attenuate Ebola virus infection. Nature Communications 11:2953.

75. Kane M, Zang TM, Rihn SJ, Zhang F, Kueck T, Alim M, Schoggins J, Rice CM, Wilson SJ, Bieniasz PD. 2016. Identification of Interferon-Stimulated Genes with Antiretroviral Activity. Cell Host Microbe 20:392-405.

76. Liu Z, Mar KB, Hanners NW, Perelman SS, Kanchwala M, Xing C, Schoggins JW, Alto NM. 2019. A NIK-SIX signalling axis controls inflammation by targeted silencing of non-canonical NF-KB. Nature 568:249-253.

77. Perng Y-C, Lenschow DJ. 2018. ISG15 in antiviral immunity and beyond. Nature Reviews Microbiology 16:423439.

78. Selleck EM, Fentress SJ, Beatty WL, Degrandi D, Pfeffer K, Virgin HWt, Macmicking JD, Sibley LD. 2013. Guanylate-binding protein 1 (Gbp1) contributes to cell-autonomous immunity against Toxoplasma gondii. PLoS pathogens 9:e1003320-e1003320.

79. Shen B, Brown K, Long S, Sibley LD. 2017. Development of CRISPR/Cas9 for Efficient Genome Editing in Toxoplasma gondii, p 79-103. In Reeves A (ed), In Vitro Mutagenesis: Methods and Protocols doi:10.1007/978-1-4939-6472-7_6. Springer New York, New York, NY.

80. Khan A, Grigg ME. 2017. Toxoplasma gondii: Laboratory Maintenance and Growth. Current protocols in microbiology 44:20C.1.1-20C.1.17.

81. Sanjana NE, Shalem O, Zhang F. 2014. Improved vectors and genome-wide libraries for CRISPR screening. Nat Methods 11:783-4.

82. Schoggins JW, Dorner M, Feulner M, Imanaka N, Murphy MY, Ploss A, Rice CM. 2012. Dengue reporter viruses reveal viral dynamics in interferon receptor-deficient mice and sensitivity to interferon effectors in vitro. Proc Natl Acad Sci U S A 109:14610-5.

83. Wilson AA, Kwok LW, Porter EL, Payne JG, McElroy GS, Ohle SJ, Greenhill SR, Blahna MT, Yamamoto K, Jean JC, Mizgerd JP, Kotton DN. 2013. Lentiviral delivery of RNAi for in vivo lineage-specific modulation of gene expression in mouse lung macrophages. Mol Ther 21:825-33.

84. Olias P, Sibley LD. 2016. Functional Analysis of the Role of Toxoplasma gondii Nucleoside Triphosphate Hydrolases I and II in Acute Mouse Virulence and Immune Suppression. Infect Immun 84:1994-2001.

85. Thomas PD, Campbell MJ, Kejariwal A, Mi H, Karlak B, Daverman R, Diemer K, Muruganujan A, Narechania A. 2003. PANTHER: a library of protein families and subfamilies indexed by function. Genome research 13:21292141.

86. Thomas PD, Kejariwal A, Guo N, Mi H, Campbell MJ, Muruganujan A, Lazareva-Ulitsky B. 2006. Applications for protein sequence-function evolution data: $\mathrm{mRNA}$ /protein expression analysis and coding SNP scoring tools. Nucleic Acids Research 34:W645-W650. 
Figure 1. Screen for interferon stimulated genes (ISGs) impacting T. gondii infection. A549 cells were treated with indicated concentrations of IFN $\gamma$ for $24 \mathrm{~h}$ and subsequently infected with the type III strain CTG expressing GFP (CTGGFP) for $36 \mathrm{~h}$ (A-C). Cells were fixed, stained with anti-GFP and anti-RFP antibodies, and imaged using a Cytation3 Imager. (A-C) Average parasitophorous vacuole (PV) size (A), PVs per field (B), and the percentage of vacuoles containing $\geq 8$ parasites (C) was quantitated for data from $36 \mathrm{~h}$ image sets. (D) Illustration of the method used to conduct the screen presented in E. (E) A549 cells were transduced with a lentiviral expression cassette cotranscriptionally expressing tagRFP and an ISG of interest in a one gene per well format. After $72 \mathrm{~h}$ cells were infected with CTG-GFP for $36 \mathrm{~h}$, fixed, stained with anti-GFP and anti-RFP antibodies, and imaged with a Cytation3 Imager. Statistical significance was determined using a two-way ANOVA with Tukey's test for post-hoc analysis. ISGs enhancing or restricting infection $>20 \%$ relative to control with $P<0.0001$ were classified as hits. Hits are shown in red and labelled. (F) WT and IDO1 ${ }^{-/}$A549 cells were infected with CTG-GFP for $96 \mathrm{~h}$. Cells were fixed, stained with anti-SAG1 antibody, and imaged with a Cytation3 Imager. Average total infected area per well is shown. Loss of IDO1 in IDO ${ }^{-/}$A549 cells was confirmed via western blot. Briefly, cells were treated with or without $1000 \mathrm{U} / \mathrm{mL}$ IFNY for 24 $\mathrm{h}$ before samples were harvested and IDO1 expression was determined. (A-C, F) Data represent the mean \pm standard deviation of three biological replicates conducted in technical triplicate. (E) Data represent mean \pm standard deviation of two biological replicates conducted in technical duplicate. Statistical significance was determined using two-way ANOVA with Tukey's test for post-hoc analysis. ns (not significant) $P>0.05, * * P<0.01, * * * * P<0.0001$.

Figure 2. IRF1 and RARRES3 restrict Toxoplasma infection. (A-B) Wild type (WT) A549 cells were either not transduced (NT) or transduced with TRIP.RARRES3 or TRIP.FLUC control and split $48 \mathrm{~h}$ later. After $60 \mathrm{~h}$, cells were stained with Hoechst 33342, SYTOX green, and imaged with a Cytation3 imager. As a positive control, cells were permeabilized by treatment with methanol $(\mathrm{MeOH})$ for 5 min prior to staining. Average cell number $(\mathrm{A})$ and the percentage of SYTOX staining cells (B) were determined. (C-F) WT A549 cells were transduced with TRIP.RARRES3 or TRIP.FLUC control and infected $72 \mathrm{~h}$ later with CTG-GFP for 36 (C-D) or 96 (E-F) h. Cells were fixed, stained with antiGFP and anti-RFP antibodies, and imaged using a Cytation3 Imager. Average PV number per field (C) and PV size (D) were quantitated for $36 \mathrm{~h}$ infections while total area infected per sample (E) and average foci size (F) were quantitated for $96 \mathrm{~h}$ infections. Data in A represent four to seven biological replicates conducted in technical triplicate. Data in B represent two to four biological replicates conducted in technical triplicate. Data in C-F represent three to four biological replicates conducted in technical triplicate. Statistical significance was determined using a Brown-Forsythe and Welch ANOVA (A-B) or a two-way ANOVA with Tukey's test for post-hoc analysis (C-F). ${ }^{*} P \leq$ $0.05, * * P<0.01$. 
745

746

747

748

749

750

751

752

753

754

755

756

757

758

759

760

761

762

763

764

765

766

767

768

769

770

771

772

773

774

775

776

777

Figure 3. Comparison of genes induced by IRF1 and IFN $\gamma$ in A549 cells. Cells were transduced with TRIP.IRF1 or TRIP.FLUC control lentivirus. Cells transduced with FLUC were further treated $72 \mathrm{~h}$ later with or without $1000 \mathrm{U} / \mathrm{mL}$ IFNy for $24 \mathrm{~h}$. All cell populations were subsequently harvested and analyzed by RNA-Seq. (A-B) Changes in gene expression relative to FLUC control expressing cells for cells treated with IFNY (A) or ectopically expressing IRF1 (B). Genes upregulated in both IRF1 expressing and IFN $\gamma$ treated cells are defined as "Shared" while genes only upregulated in one of these two cell populations are defined as "Unique". (C) Comparison of genes induced $\geq 2$ fold with a false discovery rate cutoff of 0.05 by each condition and their overlap with the ISG library used in the screen described in figure 1. (D-E) Lists of induced genes were analyzed with PANTHER gene ontology analysis. The top ten most enriched processes amongst genes induced by IFNY (D) and IRF1 (E) are shown. Redundant terms were excluded from these lists with only the most enriched version of each term remaining.

Figure 4. RARRES3 restricts Toxoplasma infection in a STAT1 independent manner.

To determine if restriction of $T$. gondii growth was STAT1 dependent, STAT1 ${ }^{--}$A549 cells were generated. To confirm complete insensitivity to interferon treatment, WT or STAT1 ${ }^{-1}$ A549 cells were treated with or without 4,000 U/mL IFN $\gamma$ for $6 \mathrm{~h}$, fixed, stained with anti-IRF1 antibodies, and imaged with a Cytation3 Imager. (A) Representative images and (B) quantitation are shown. Scale bar $=50 \mu \mathrm{m}$. (C-F) STAT1 ${ }^{-1}$ A549 cells were transduced with TRIP.RARRES3 or TRIP.FLUC control and infected $72 \mathrm{~h}$ later with CTG-GFP for 36 (C-D) or 96 (E-F) h. Cells were fixed, stained with antiGFP and anti-RFP antibodies, and imaged using a Cytation3 Imager. Average PV number per field (C) and PV size (D) were quantitated for $36 \mathrm{~h}$ infections while total area infected per sample (E) and average foci size (F) were quantitated for $96 \mathrm{~h}$ infections. HeLa reporter cell lines expressing GAS-LUC (G), kB-LUC (H), ISRE-GLUC (I), and GFPLUC (J) were either not transduced (NT) or transduced with TRIP.RARRES3, TRIP.FLUC, or TRIP.GFP. After $72 \mathrm{~h}$, cells were mock treated or treated with $100 \mathrm{U} / \mathrm{mL}$ IFN $\beta$ or IFN $\gamma$ as indicated and infected with CTG-GFP for 36 h. Cells were harvested for luciferase assay. Data in B represent means \pm S.D. of four biological replicates conducted in technical duplicate. Data in C-F represent means \pm standard deviation of four biological replicates conducted in technical triplicate. Data represent means \pm S.D. of two $(G)$ or three $(\mathrm{H}-\mathrm{I})$ biological replicates conducted in technical duplicate. Statistical significance was determined using two-way ANOVA with Tukey's test for post-hoc analysis except for $\mathrm{D}$ where Mann-Whitney's U test was used. $* P \leq 0.05, * * P<0.01, * * * P<0.001, * * * * P<0.0001$.

Figure 5-figure supplement 1. RARRES3 does not restrict infection of Type I or II strains of Toxoplasma gondii. A549 cells were transduced with TRIP.RARRES3 and infected $72 \mathrm{~h}$ later with a type I strain expressing GFP (RH88-GFP) (A-B) or a type II strain expressing GFP (Me49-GFP) (C-D) for $4 \mathrm{~d}$ or $6 \mathrm{~d}$ respectively. Cells were fixed, stained with anti-GFP and anti-RFP antibodies, and imaged using a Cytation3 Imager. Average total infected area per well (A, C) and average area of infection foci $(B, D)$ is shown. Data represent means \pm standard deviation of two to three biological 
replicates conducted in technical triplicate. Statistical significance was determined using two-way ANOVA with Tukey's test for post-hoc analysis.

Figure 5. RARRES3 deficiency partially reverses IFN $\gamma$ mediated restriction of Toxoplasma infection. (A-B) A549s were transduced with V5 tagged WT RARRES3 or the catalytically inactive mutants C113A or C133S for $72 \mathrm{~h}$. (A) Cells were infected with CTG-GFP for 96h. Cells were harvested, stained with anti-GFP and anti-RFP antibodies, and imaged with a Cytation3 Imager. The total area infected per sample is shown. (B) Western blot from lysates prepared with above RARRES3 expressing cells. Membranes were probed with mouse anti-actin and mouse anti-V5 antibodies overnight followed by goat anti-mouse 680RD and imaged with a LI COR Odyssey scanner. RARRES3 ${ }^{--}$A549s or wildtype cells transduced with a nontargeting CRISPR/Cas9 sgRNA were transduced with Cas9 resistant TRIP.RARRES3 or TRIP.FLUC as indicated. $72 \mathrm{~h}$ later, cells were treated with or without $100 \mathrm{U} / \mathrm{mL}$ IFN $\gamma$ for $24 \mathrm{~h}$ as indicated and subsequently infected with CTG-GFP for $96 \mathrm{~h}$. Cells were harvested, stained with anti-GFP and anti-RFP antibodies, and imaged with a Cytation3 Imager. (C) Representative images and (D) quantitation are shown. Scale bar $=500 \mu \mathrm{m}$. (E) RARRES3 ${ }^{-/-}$or RARRES3 ${ }^{+/+}$A549 cells transduced with a nontargeting CRISPR/Cas9 control sgRNA were transduced with TRIP.FLUC or TRIP.IRF1 derived lentivirus. After 72 h, cells were infected with CTG-GFP for 96 h, harvested, stained with anti-GFP and anti-RFP antibodies, and imaged with a Cytation3 Imager. Average total infected area per well is shown. Data represent means \pm standard deviation of three $(A)$ or four (D-E) biological replicates conducted in technical triplicate. Statistical significance was determined using two-way ANOVA with Tukey's test for post-hoc analysis. ns $P>0.05, * * P<0.01, * * * * P<0.0001$

Figure 6. RARRES3 promotes premature egress of $\boldsymbol{T}$. gondii. A549 cells were transduced with TRIP.RARRES3 or TRIP.FLUC control and infected $72 \mathrm{~h}$ later with CTG-GFP for 36 (A,B, D, F), 50 (C) or 72 (E) h. Cells were treated with the cell death inhibitors Z-VAD-FMK $(50 \mu \mathrm{M})$, GSK'963 (1 $\mu \mathrm{M})$, GSK'872 (5 $\mu \mathrm{M})$, NSA (10 $\mu \mathrm{M})$, and Z-YVAD-FMK (10 $\mu \mathrm{M})$ or the parasite egress inhibitor compound $1(5 \mu \mathrm{M})$ as indicated during infection. (A, $B, E, F)$ Cell supernatant was collected after infection and lactate dehydrogenase (LDH) activity was determined to measure cell lysis. As a control to measure maximal LDH release, cells were lysed before supernatant collection. (C) Live infection was imaged every 15 min starting $2 \mathrm{~h}$ postinfection until $50 \mathrm{~h}$ postinfection. Time of parasite egress was recorded for at least 100 PVs per condition per replicate. Percentage of total parasites egressed by the end of each hour is indicated. (D) Cells were fixed, stained with anti-RFP and anti-GFP antibodies, and imaged with a Cytation3 Imager. Average cells per field are shown. Data represent the means \pm standard deviation (A, B, D-F) or standard error of the mean (C) of three to five biological replicates conducted in technical duplicate (A, B, D-F), or singlet (C). Statistical significance was determined using two-way ANOVA with Tukey's test for post-hoc analysis. ns $P>0.05, * P \leq 0.05, * * * P<0.001$, $* * * * P<0.0001$. 
811 Figure 6-figure supplement 1. Compound 1 prevents host cell death during infection. (A-C) A549 cells were

812

813

814

815

816

817

818

819

820

821

822

823

824

825

826

827

828

829

830

831

832

833

834

835

836

837

838

839

840

841

transduced with TRIP.RARRES3 or TRIP.FLUC control and infected $72 \mathrm{~h}$ later with CTG-GFP for $36 \mathrm{~h}(\mathrm{~A})$ or $72 \mathrm{~h}$ (B-C).

Cells were stained with Hoechst 33342, propidium iodide, and imaged with a Cytation3 imager. As a positive control, cells were permeabilized by treatment with methanol $(\mathrm{MeOH})$ for 5 min prior to staining. The percentage of propidium iodide staining cells (A, B) and average cell number per field (C) were determined. (D-F) HFF cells were pretreated with or without IFNy for $24 \mathrm{~h}$ and subsequently infected with CTG-GFP for $36 \mathrm{~h}$. Cells were stained with Hoechst 33342, propidium iodide, and imaged with a Cytation3 imager. As a positive control, cells were permeabilized by treatment with methanol $(\mathrm{MeOH})$ for 5 min prior to staining. (D) Representative images are shown. Scale bar $=50 \mu \mathrm{m}$. Average cell number $(\mathrm{E})$ and the percentage of propidium iodide staining cells $(\mathrm{F})$ were determined. Data represent means \pm standard deviation of two or three biological replicates conducted in technical duplicate. Statistical significance was determined using two-way ANOVA with Tukey's test for post-hoc analysis. ${ }^{* * *} P$ $<0.001, * * * * P<0.0001$.

Figure 7. IFN $\boldsymbol{Y}$-dependent host cell death during infection in HFFs is partially RARRES3 dependent. (A-B) HFF cells were transduced with TRIP.RARRES3 or TRIP.FLUC control and infected $72 \mathrm{~h}$ later with CTG-GFP for $96 \mathrm{~h}$. Cells were fixed, stained with anti-GFP and anti-RFP antibodies, and imaged using a Cytation3 Imager. Total infected area per well (A) and average number of infection foci (B) is shown. (C-D) WT HFFs expressing a nontargeting sgRNA control or RARRES3 deficient HFFs were pretreated with or without $1000 \mathrm{U} / \mathrm{mL}$ IFN $y$ for $24 \mathrm{~h}$. (C) Cells were infected with CTGGFP for $36 \mathrm{~h}$. Supernatant was collected and lactate dehydrogenase (LDH) activity was determined. As a control to measure maximal LDH release, cells were lysed before supernatant collection. (D) Cells were infected with CTG-GFP for $96 \mathrm{~h}$. Samples were treated as in A. Total infected area per sample is shown. (E) HFFs were infected with CTG-GFP for $36 \mathrm{~h}$ in the presence or absence of $5 \mu \mathrm{M}$ Compound 1 . Supernatant was collected and LDH activity was determined. Data represent means \pm standard deviation of three $(A, B, D, E)$ or four (C) biological replicates conducted in technical duplicate $(A, B, D, E)$ or singlet $(C)$. Statistical significance was determined using two-way ANOVA with Tukey's test for post-hoc analysis. ${ }^{*} P \leq 0.05, * * * P<0.001, * * * * P<0.0001$.

Supplementary file 1. Summary of over-expression screen in A549 cells.

Supplementary file 2. List of genes induced by IRF1 ectopic expression or IFN $\gamma$ treatment in A549 cells.

Supplementary file 3. Comparison of genes induced by IRF1 or IFN $\gamma$ with genes in the type II ISG screen library.

Supplementary file 4 . List of primer sets used. 
Rich Media

844 Video 1. Live imaging of FLUC control ectopically expressing A549s infected with CTG-GFP in 15 min intervals. A549 845 cells were transduced with TRIP.FLUC control and infected $72 \mathrm{~h}$ later with CTG-GFP. Live infection was imaged every $84615 \mathrm{~min}$ starting $12 \mathrm{~h}$ postinfection until $50 \mathrm{~h}$ postinfection.

847 Video 2. Live imaging of RARRES3 ectopically expressing A549s infected with CTG-GFP in 15 min intervals. A549 848 cells were transduced with TRIP.RARRES3 and infected $72 \mathrm{~h}$ later with CTG-GFP. Live infection was imaged every 15 849 min starting $12 \mathrm{~h}$ postinfection until $50 \mathrm{~h}$ postinfection.

Source data files

Figure 1 - Source Data 1. Vacuole size quantitation following CTG-GFP infection of IFN pretreated A549 cells.

Figure 1 - Source Data 2. Vacuole number quantitation following CTG-GFP infection of IFN pretreated A549 cells. Figure 1 - Source Data 3. Quantitation of the percentage of vacuoles containing 8 or more parasites following CTGGFP infection of IFN pretreated A549 cells.

Figure 1 - Source Data 4. Numerical value summary for the results of the ISG screen. The complete dataset is presented in Supplementary file 1.

Figure 1 - Source Data 5. Quantitation of the total image area infected after CTG-GFP infection of WT or IDO1 ${ }^{-/}$ A549 cells.

Figure 1 - Source Data 6. Contrast enhanced and labelled actin western blot.

Figure 1 - Source Data 7. Unmodified actin western blot.

Figure 1 - Source Data 8. Contrast enhanced and labelled ID01 western blot.

Figure 1 - Source Data 9. Unmodified IDO1 western blot.

Figure 2 - Source Data 1. Cell counts per field for cells ectopically expressing ISG screen hits.

Figure 2 - Source Data 2. Percentage of A549s ectopically expressing ISG screen hits that stained positive for SYTOX Green.

Figure 2 - Source Data 3. Number of vacuoles counted after infection of A549s ectopically expressing ISG screen hits with CTG-GFP for $36 \mathrm{~h}$.

Figure 2 - Source Data 4. Quantitation of vacuole size after infection of A549s ectopically expressing ISG screen hits with CTG-GFP for $36 \mathrm{~h}$.

Figure 2 - Source Data 5. Quantitation of total area infected per sample after infection of A549s ectopically expressing ISG screen hits with CTG-GFP for $96 \mathrm{~h}$.

Figure 2 - Source Data 6. Quantitation of average infection foci size formed after infection of A549s ectopically expressing ISG screen hits with CTG-GFP for $96 \mathrm{~h}$. 
Figure 3 - Source Data 1. Differential expression of genes after IFN $\gamma$ treatment relative to mock control.

Figure 3 - Source Data 2. Differential expression of genes in IRF1 over-expressing cells relative to FLUC expressing control cells.

Figure 3 - Source Data 3. Gene ontology term enrichment for genes significantly induced by IFN $\gamma$ treatment.

Figure 3 - Source Data 4. Gene ontology term enrichment for genes significantly induced by IRF1 over-expression.

Figure 4 - Source Data 1. Quantitation of the percentage of IRF1 staining cells after IFN $\gamma$ treatment of WT or STAT1 I- A549 cells.

Figure 4 - Source Data 2. Quantitation of the number of vacuoles formed following CTG-GFP infection of RARRES3 or FLUC ectopically expressing STAT1 ${ }^{\%}$ A549 cells.

Figure 4 - Source Data 3. Vacuole size quantitation following CTG-GFP infection of RARRES3 or FLUC ectopically expressing STAT1 $^{-/-}$A549 cells.

Figure 4 - Source Data 4. Quantitation of total infected area per sample after infection of STAT1 ${ }^{\% \text { A549s }}$ ectopically expressing RARRES3 or FLUC with CTG-GFP for $96 \mathrm{~h}$.

Figure 4 - Source Data 5. Quantitation of average infection foci size formed after infection of STAT1 ${ }^{-/}$A549s ectopically expressing RARRES3 or FLUC with CTG-GFP for $96 \mathrm{~h}$.

Figure 4 - Source Data 6. Luminescence values from luciferase assays conducted on lysates from cells expressing a GAS-LUC reporter and RARRES3.

Figure 4 - Source Data 7. Luminescence values from luciferase assays conducted on lysates from cells expressing a KB-LUC reporter and RARRES3.

Figure 4 - Source Data 8. Luminescence values from luciferase assays conducted on cell supernatant from cells expressing an ISRE-GLUC reporter and RARRES3.

Figure 4 - Source Data 9. Luminescence values from luciferase assays conducted on lysates from cells expressing a GFP-LUC reporter control and RARRES3.

Figure 5 - Source Data 1. Quantitation of total infected area per sample after infection of A549s ectopically expressing WT RARRES3 and mutants with CTG-GFP for $96 \mathrm{~h}$.

Figure 5 - Source Data 2. Contrast enhanced and labelled actin western blot.

Figure 5 - Source Data 3. Unmodified actin western blot.

Figure 5 - Source Data 4. Contrast enhanced and labelled V5 tag western blot.

Figure 5 - Source Data 5. Unmodified V5 tag western blot.

Figure 5 - Source Data 6. Quantitation of total infected area per sample after infection of IFN $\gamma$ pretreated WT or RARRES3 $^{-/-}$A549s with CTG-GFP for $96 \mathrm{~h}$.

Figure 5 - Source Data 7. Quantitation of total infected area per sample after infection of WT or RARRES3 ${ }^{\%}$ A549s ectopically expressing IRF1 with CTG-GFP for $96 \mathrm{~h}$.

Figure 5-figure supplement 1 - Source Data 1. Quantitation of total infected area per sample after infection of A549s ectopically expressing RARRES3 or FLUC with RH88-GFP. 
Figure 5-figure supplement 1 - Source Data 2. Quantitation of average infection foci size formed after infection of A549s ectopically expressing RARRES3 or FLUC with RH88-GFP.

Figure 5-figure supplement 1 - Source Data 3. Quantitation of total infected area per sample after infection of A549s ectopically expressing RARRES3 or FLUC with Me49-GFP.

Figure 5-figure supplement 1 - Source Data 4. Quantitation of average infection foci size formed after infection of A549s ectopically expressing RARRES3 or FLUC with Me49-GFP.

Figure 6 - Source Data 1. Absorbance values for lactate dehydrogenase activity assays using supernatants from RARRES3 or FLUC ectopically expressing A549 cells infected with CTG-GFP for $36 \mathrm{~h}$.

Figure 6 - Source Data 2. Absorbance values for lactate dehydrogenase activity assays using supernatants from RARRES3 or FLUC ectopically expressing A549 cells infected with CTG-GFP for $36 \mathrm{~h}$ in the presence of Compound 1.

Figure 6 - Source Data 3. Quantitation of the time of egress in hours for parasites egressing from RARRES3 or FLUC ectopically expressing A549s.

Figure 6 - Source Data 4. Cell count per field after infection of RARRES3 or FLUC ectopically expressing A549s with CTG-GFP in the presence of Compound 1.

Figure 6 - Source Data 5. Absorbance values for lactate dehydrogenase activity assays using supernatants from RARRES3 or FLUC ectopically expressing A549 cells infected with CTG-GFP for $72 \mathrm{~h}$ in the presence of Compound 1.

Figure 6 - Source Data 6. Absorbance values for lactate dehydrogenase activity assays using supernatants from RARRES3 or FLUC ectopically expressing A549 cells infected with CTG-GFP in the presence of cell death inhibitors.

Figure 6-figure supplement 1 - Source Data 1. Percentage of cells staining with propidium iodide after infection of RARRES3 or FLUC ectopically expressing A549s with CTG-GFP for $36 \mathrm{~h}$ in the presence of Compound 1.

Figure 6-figure supplement 1 - Source Data 2. Percentage of cells staining with propidium iodide after infection of RARRES3 or FLUC ectopically expressing A549s with CTG-GFP for $72 \mathrm{~h}$ in the presence of Compound 1.

Figure 6-figure supplement 1 - Source Data 3. Cell count per field after infection of RARRES3 or FLUC ectopically expressing A549s with CTG-GFP for $72 \mathrm{~h}$ in the presence of Compound 1.

Figure 6-figure supplement 1 - Source Data 4. Cell count per field after infection of IFNy pretreated HFFs with CTGGFP for $36 \mathrm{~h}$ in the presence of Compound 1.

Figure 6-figure supplement 1 - Source Data 5. Percentage of cells staining with propidium iodide after infection of IFN $\gamma$ pretreated HFFs with CTG-GFP for $36 \mathrm{~h}$ in the presence of Compound 1.

Figure 7 - Source Data 1. Quantitation of total infected area per sample after infection of HFFs ectopically expressing RARRES3 or FLUC with CTG-GFP for $96 \mathrm{~h}$.

Figure 7 - Source Data 2. Quantitation of average infection foci size formed after infection of HFFs ectopically expressing RARRES3 or FLUC with CTG-GFP for $96 \mathrm{~h}$.

Figure 7 - Source Data 3. Absorbance values for lactate dehydrogenase activity assays using supernatants from IFN $\gamma$ pretreated WT or RARRES3 ${ }^{-/-}$HFF cells infected with CTG-GFP.

Figure 7 - Source Data 4. Quantitation of total infected area per sample after infection of IFNץ pretreated WT or RARRES3 $^{-/-}$HFFs ectopically expressing RARRES3 or FLUC with CTG-GFP for $96 \mathrm{~h}$.

Figure 7 - Source Data 5. Absorbance values for lactate dehydrogenase activity assays using supernatants from IFN $\gamma$ pretreated HFF cells infected with CTG-GFP in the presence of Compound 1. 
948 Video 1 - Source Data 1. GFP channel of live video microscopy for CTG-GFP infection in A549 cells ectopically 949 expressing FLUC control.

950 Video 1 - Source Data 2. Phase channel of live video microscopy for CTG-GFP infection in A549 cells ectopically 951 expressing FLUC control.

952 Video 2 - Source Data 1. GFP channel of live video microscopy for CTG-GFP infection in A549 cells ectopically 953 expressing RARRES3 control.

954 Video 2 - Source Data 2. Phase channel of live video microscopy for CTG-GFP infection in A549 cells ectopically 955 expressing RARRES3 control. 
A

Vacuole Size B

Vacuole Number

C Vacuoles Containing
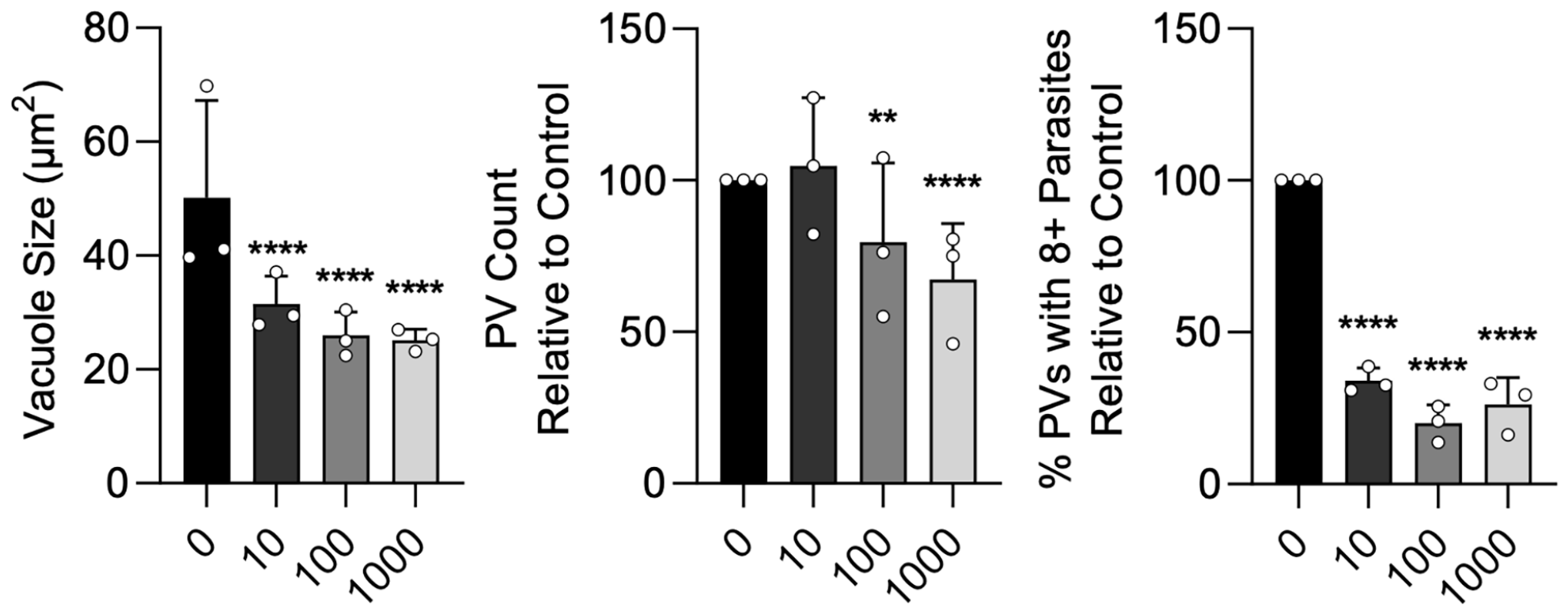

U/mL IFNy

U/mL IFNy

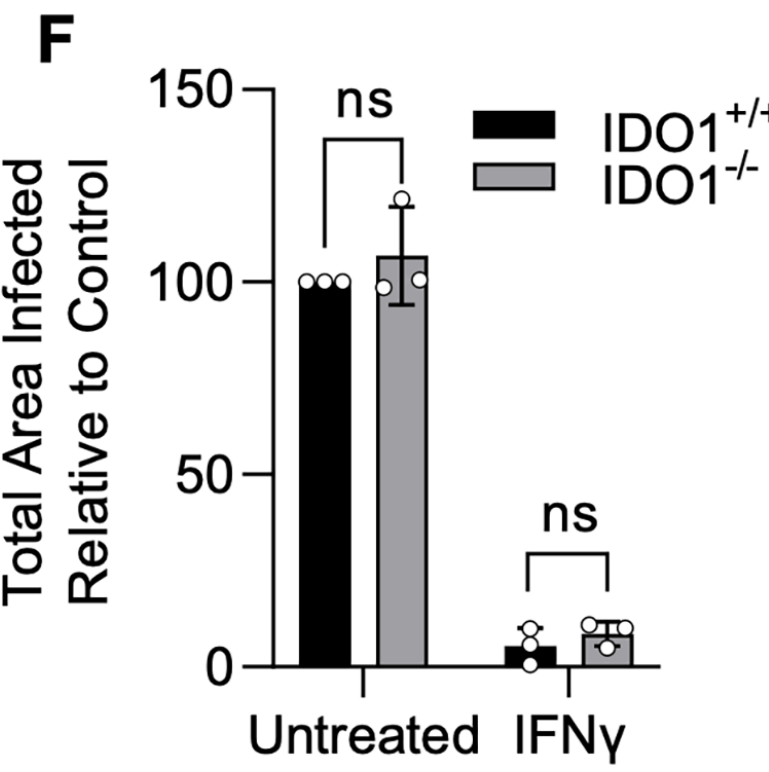

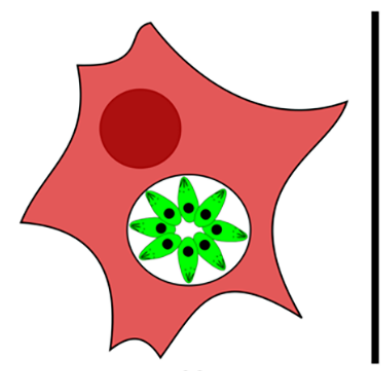

No effect

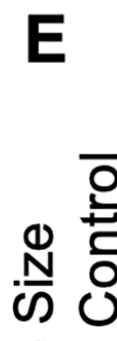

递

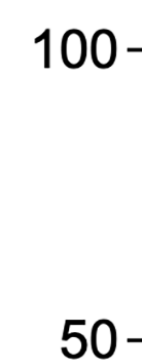

IFNy

Genotype

IDO1

actin

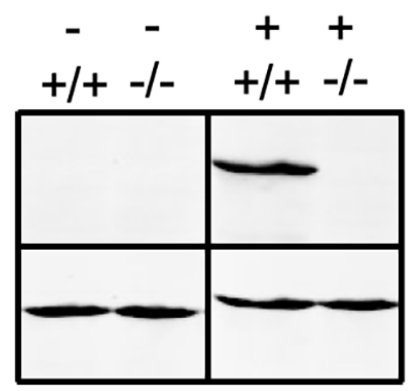


B
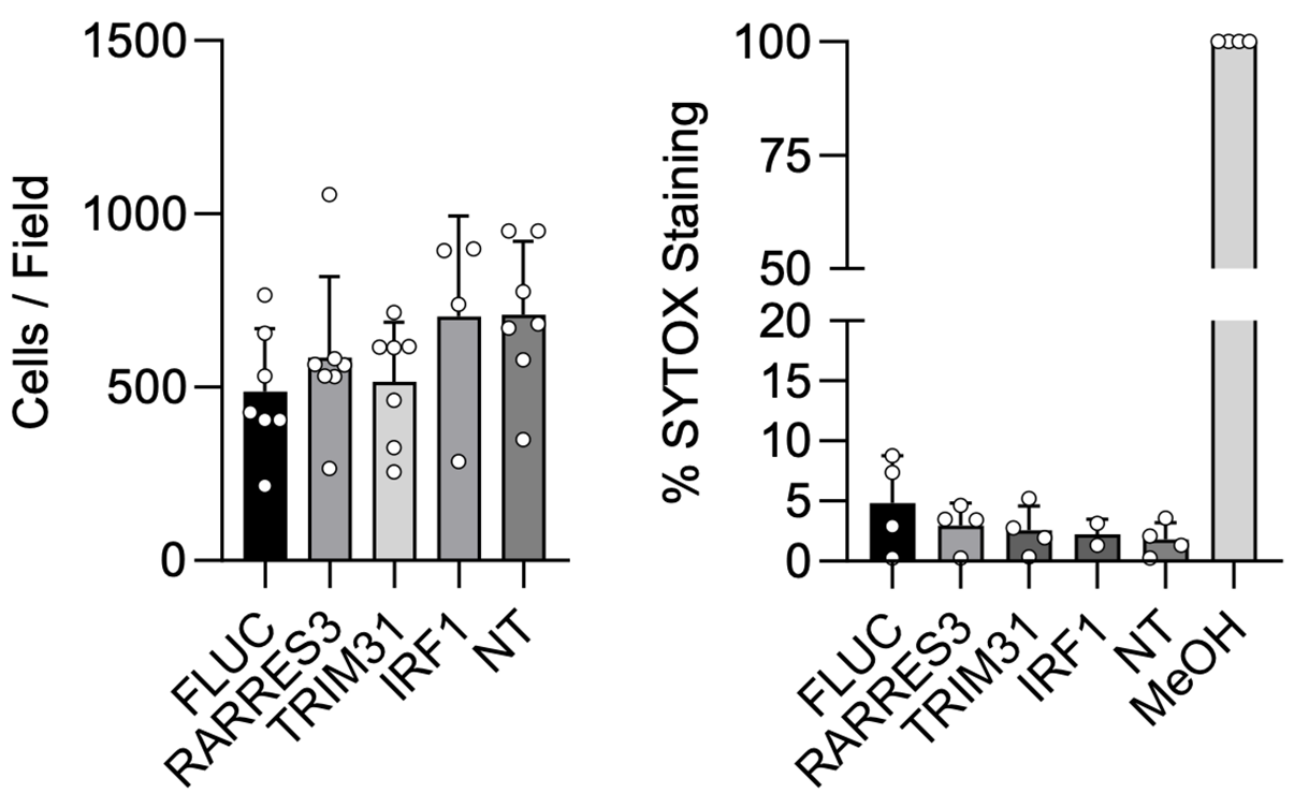

C Vacuole Number

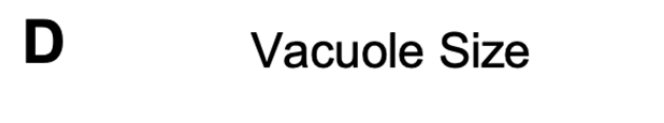

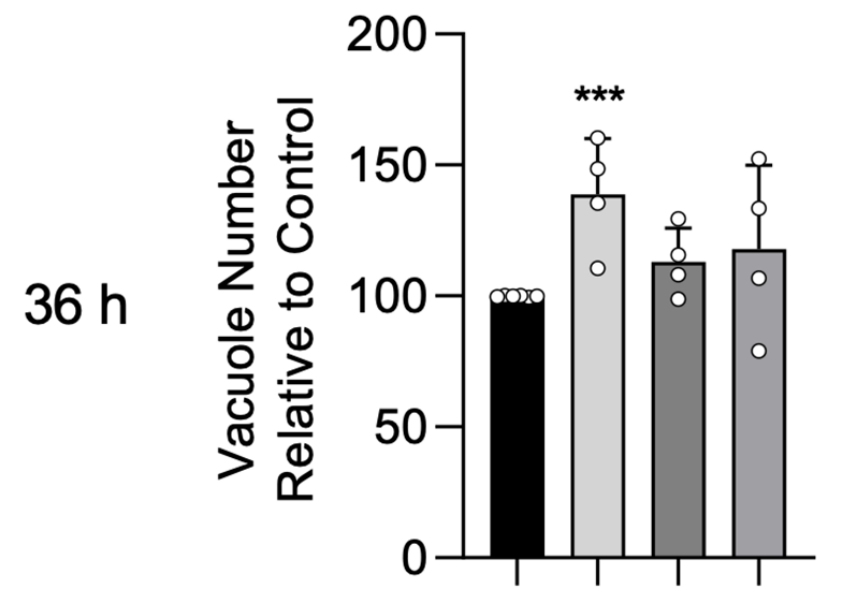

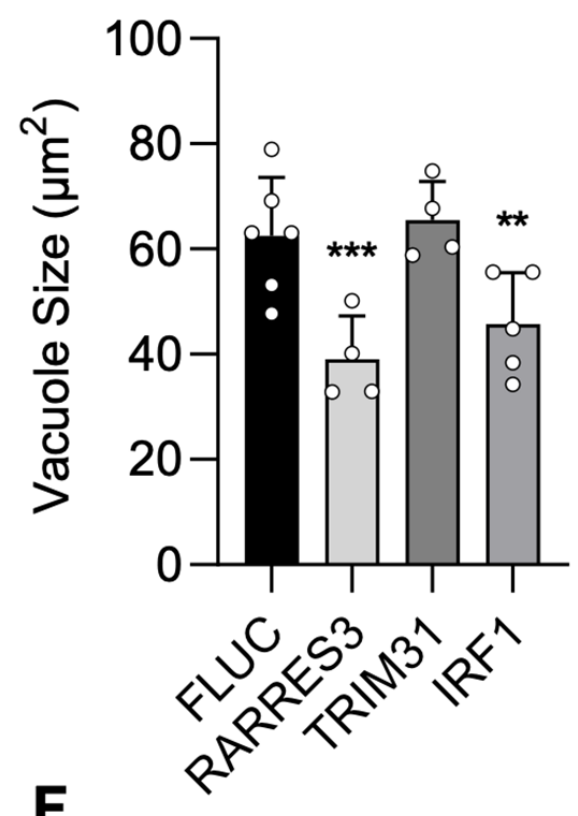

E Total Infected Area

F

Foci Size

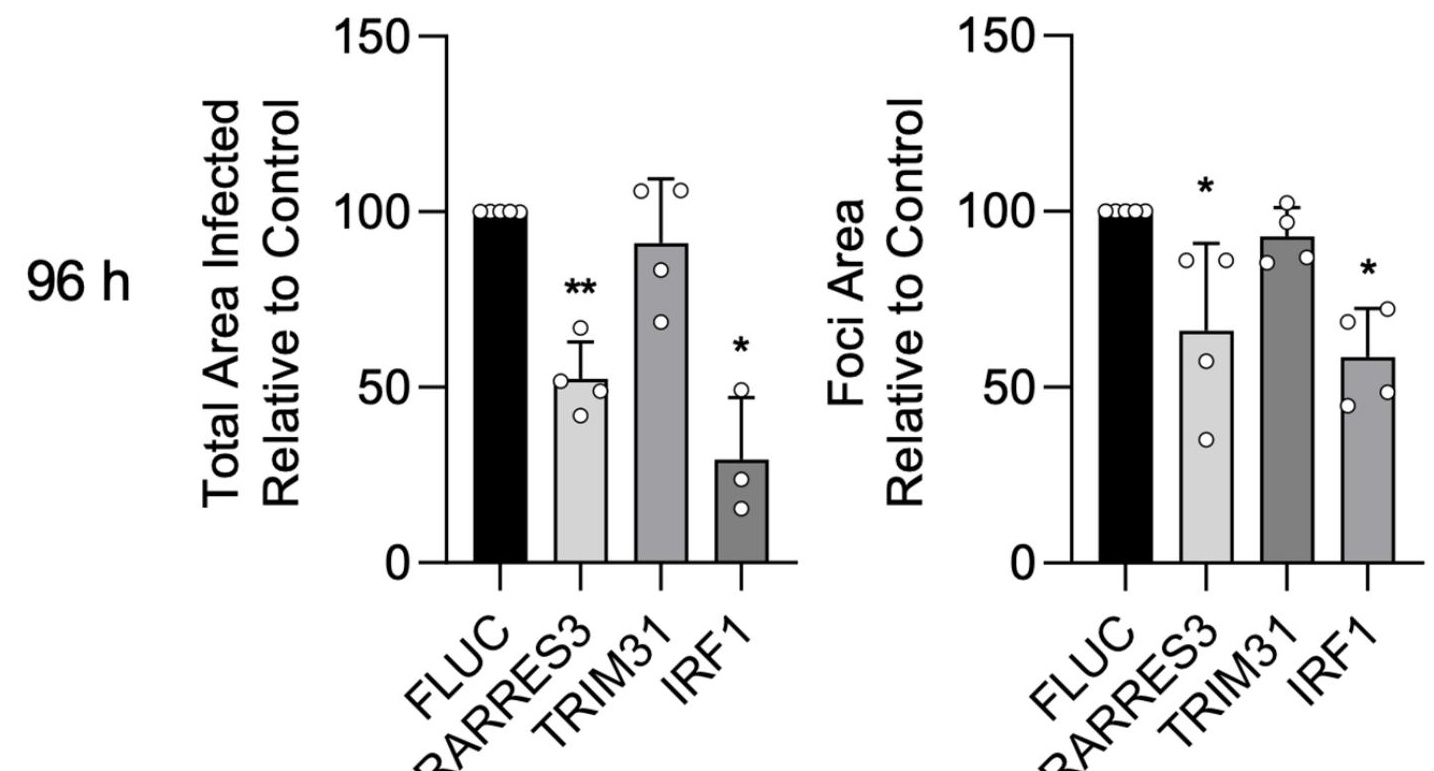


- Upregulated, Shared, Included in Screen

$\bigcirc$ Upregulated, Shared, Not in Screen

Upregulated, Unique, Included in Screen
Upregulated, Unique, Not in Screen

$\bigcirc$ Below cutoff
A

IFNy

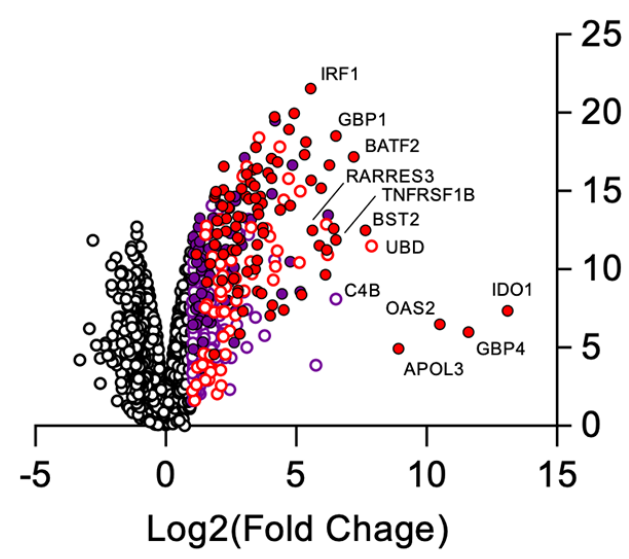

D

type I interferon signaling pathway cellular response to type I interferon interferon-gamma-mediated signaling pathway negative regulation of viral process response to interferon-gamma defense response to virus defense response to symbiont antigen processing and presentation regulation of innate immune response cytokine-mediated signaling pathway
B

B IRF1
Top 100 IRF1 induced
Top 100 IFN $\gamma$ induced genes

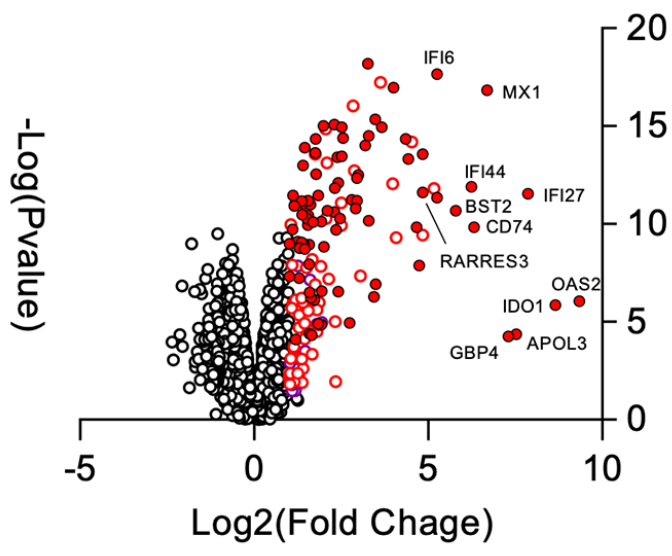

IFNY

Fold Enrichment

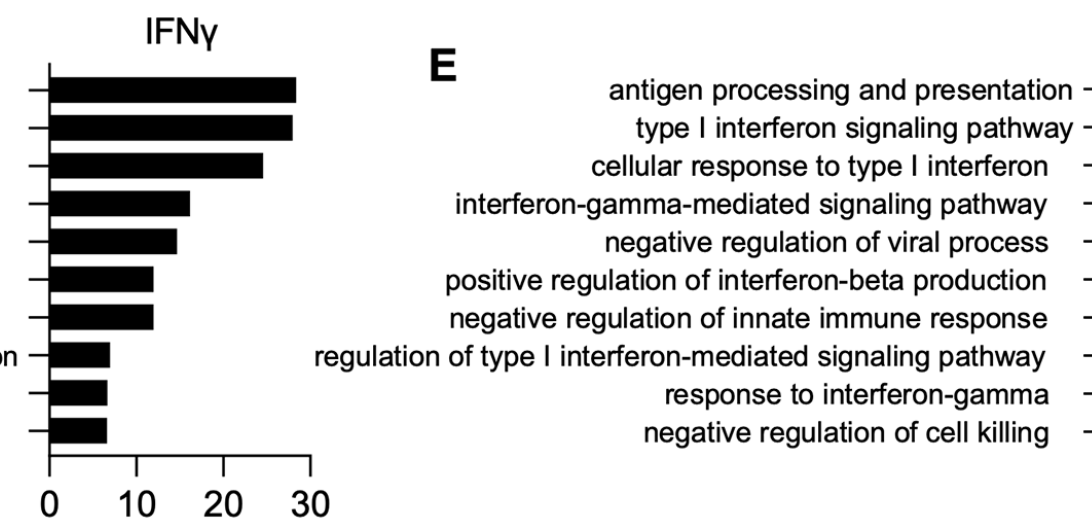

E

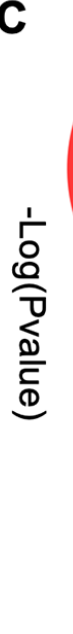

13

18

51

18

329

Genes in screen library in

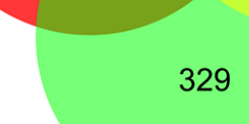

IRF1

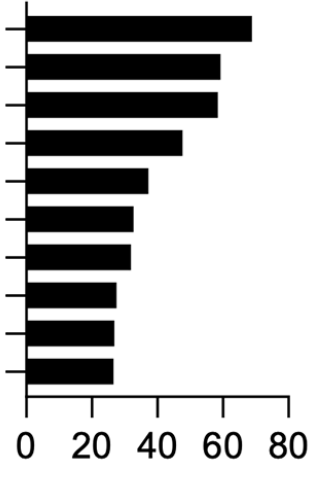

Fold Enrichment 
A

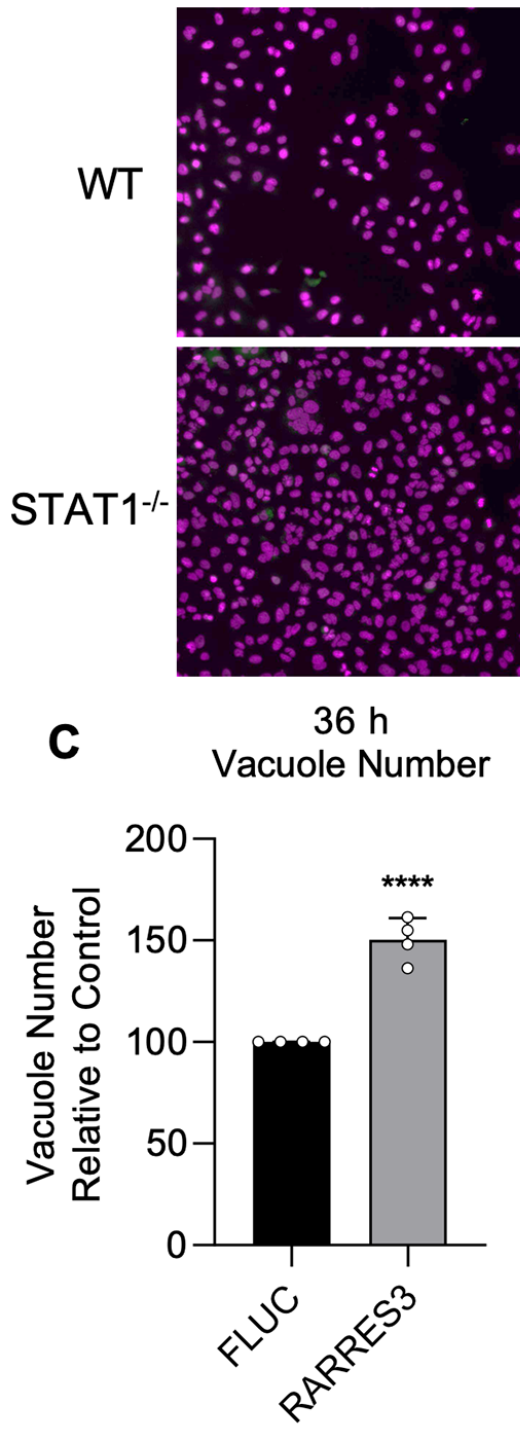

G



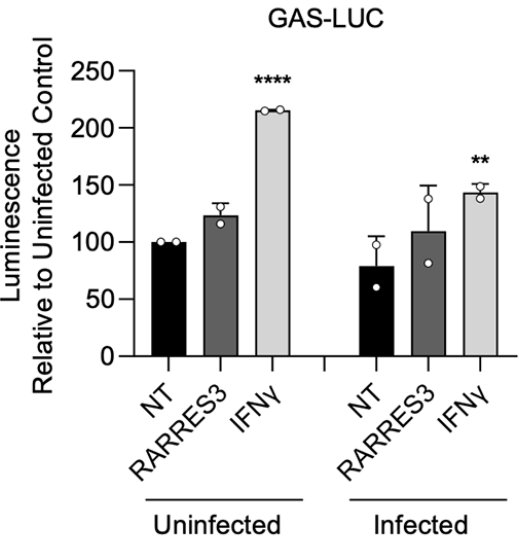

$\mathrm{IFNy}+$

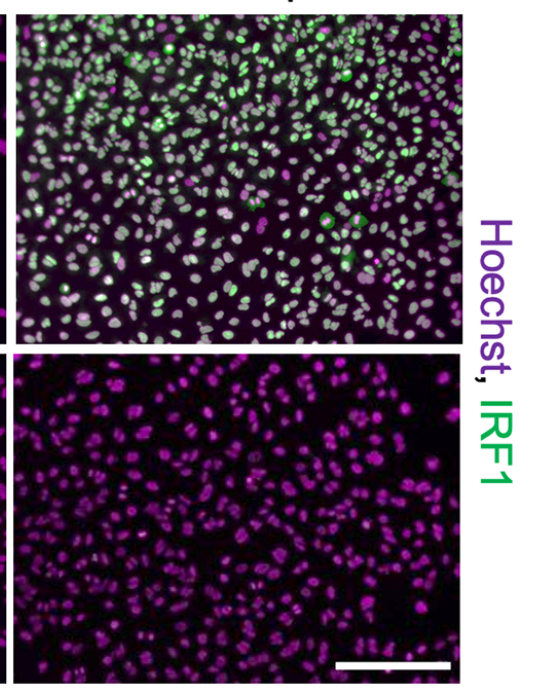

D $\quad \begin{gathered}36 \mathrm{~h} \\ \text { Vacuole Size }\end{gathered}$
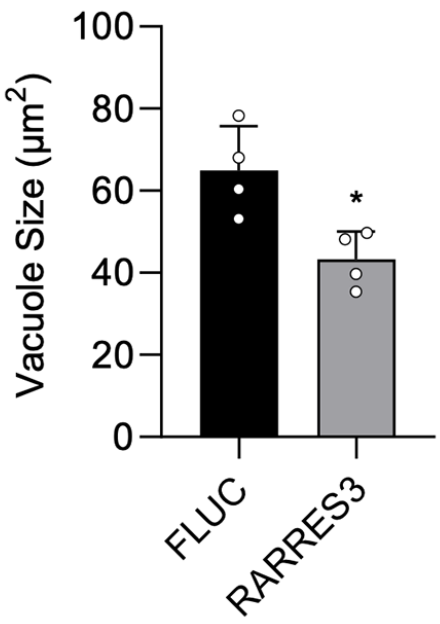

$\mathrm{H}$
E

B

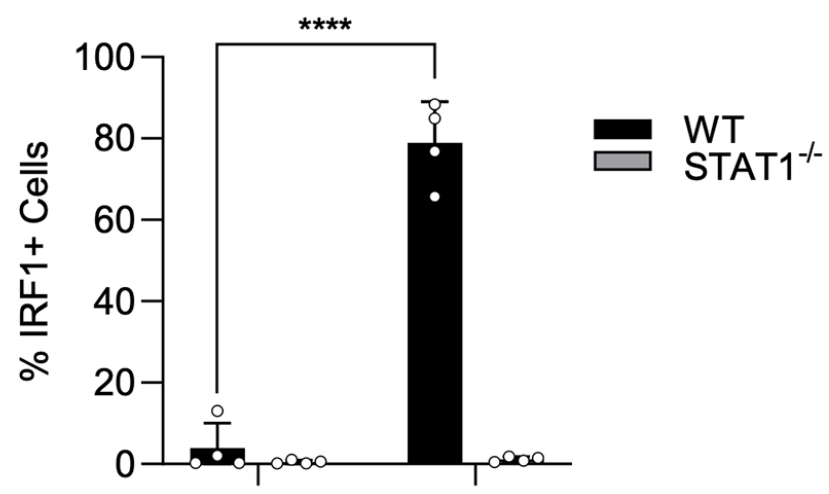

IFNY - IFNY +

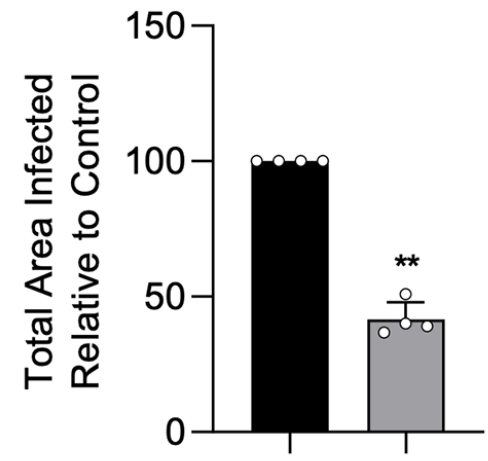

kB-LUC

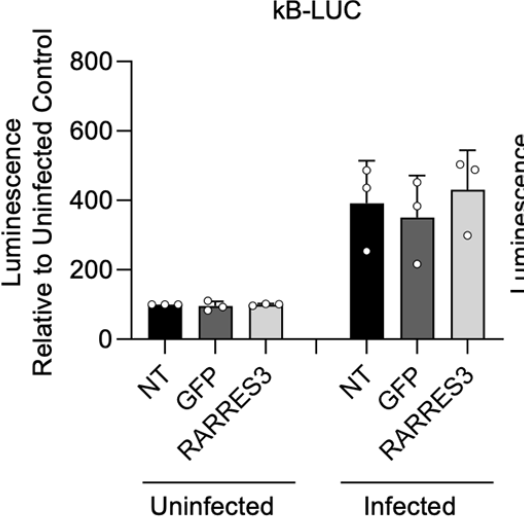

$96 \mathrm{~h}$ Total Infected Area

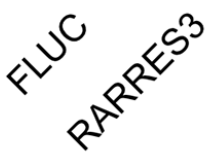

F

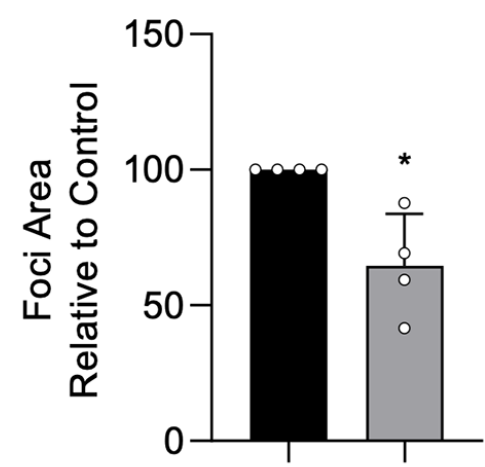

I

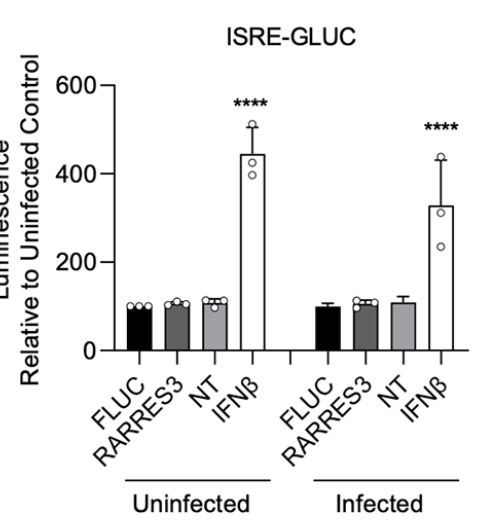

$96 \mathrm{~h}$

Foci Size

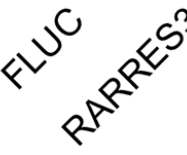

$J$

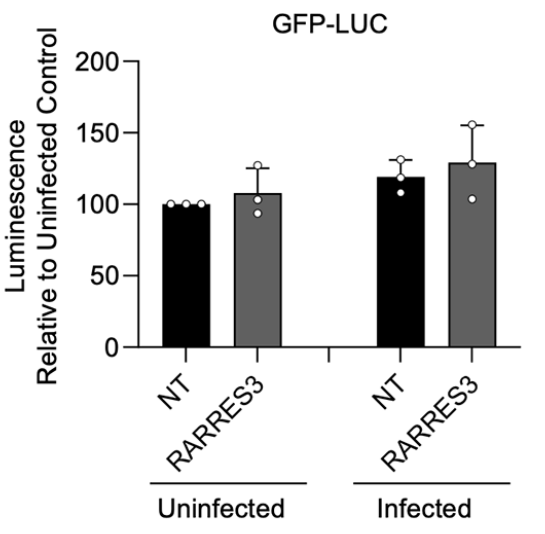




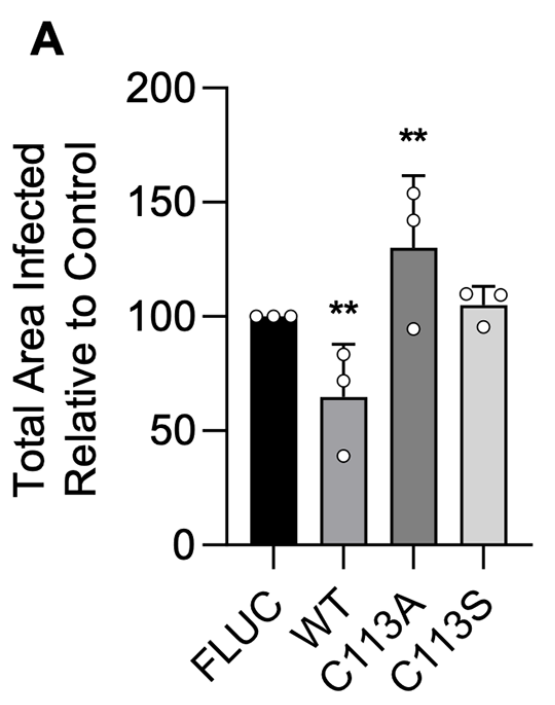

C

C

RARRES3 ${ }^{-1-}$

+ RARRES3

RARRES3--

- IFNY
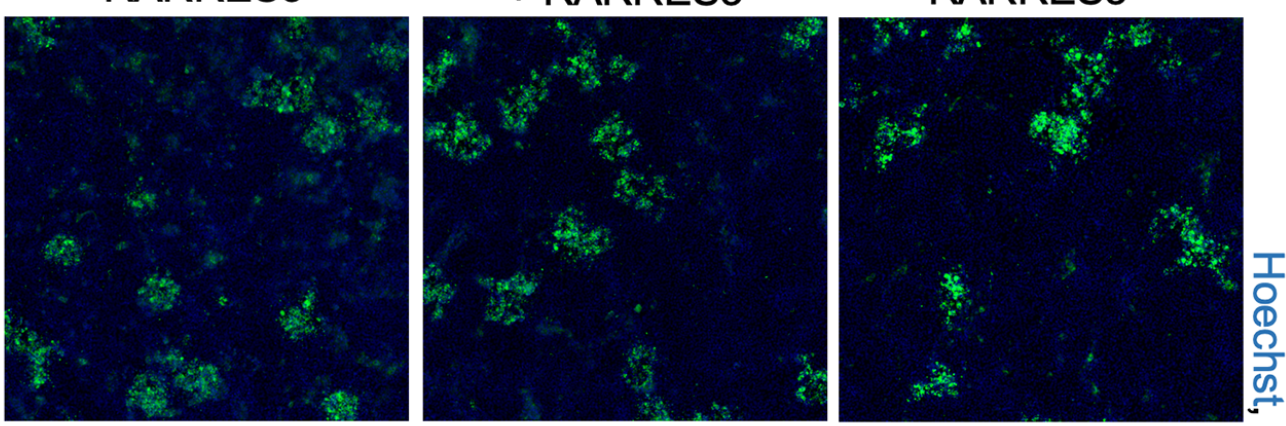

$+\mathrm{IFNY}$
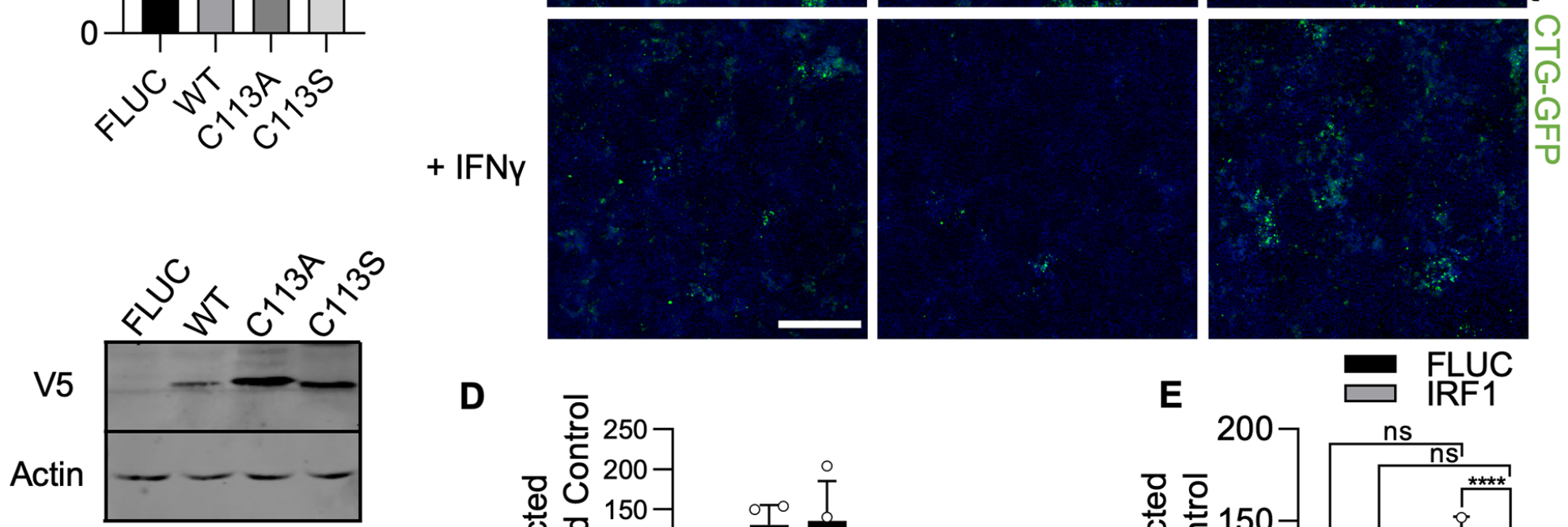

D

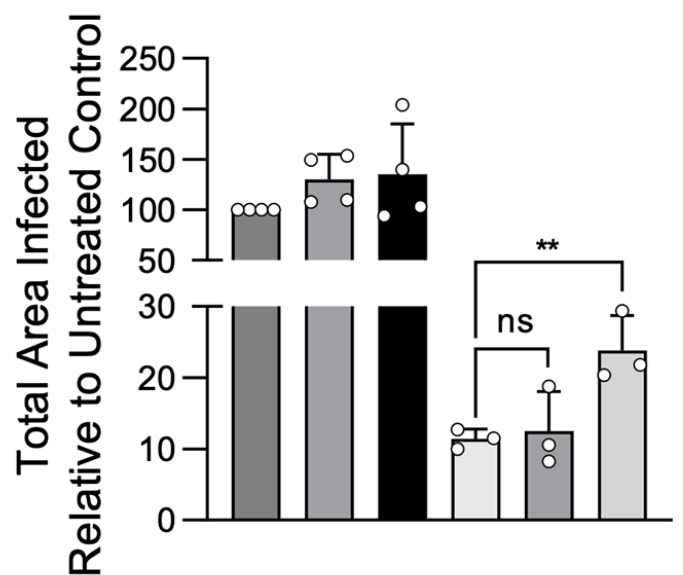

RARRES3 Genotype +/+ $\quad-/-\quad-/-\quad$ +/+ $\quad$-/- $\quad-/-$

TRIP.RARRES3

TRIP.FLUC

IFNY

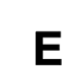

E

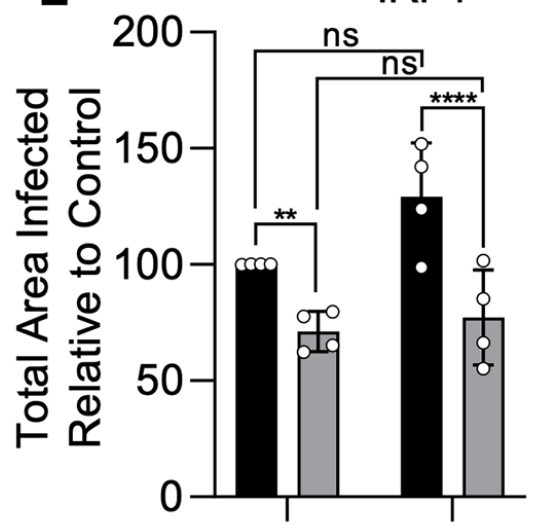

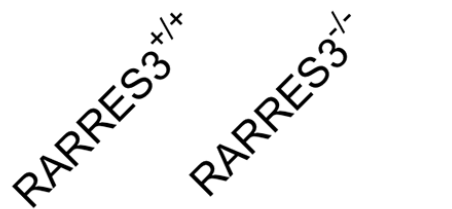


A

Total Infected Area

B
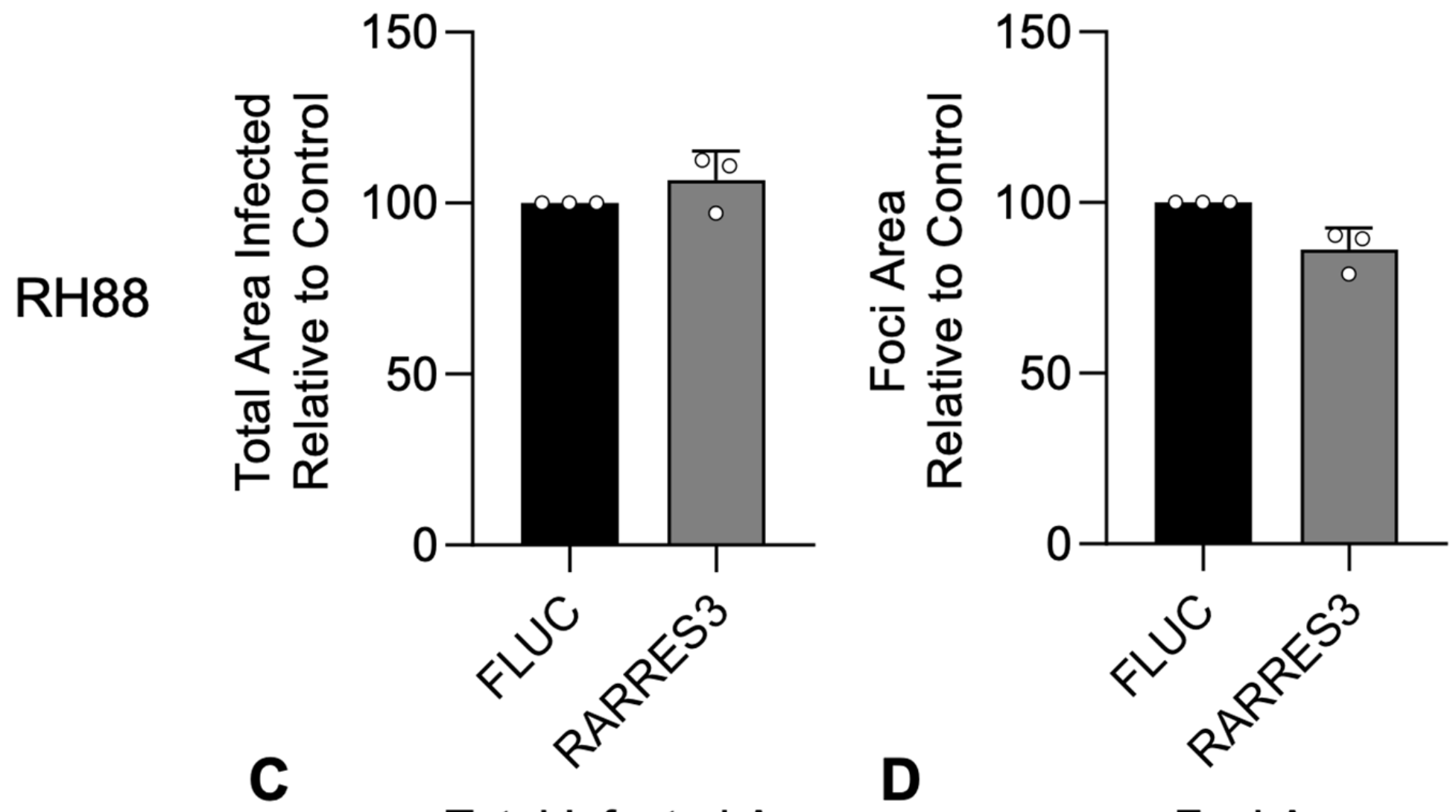

Total Infected Area

Foci Area
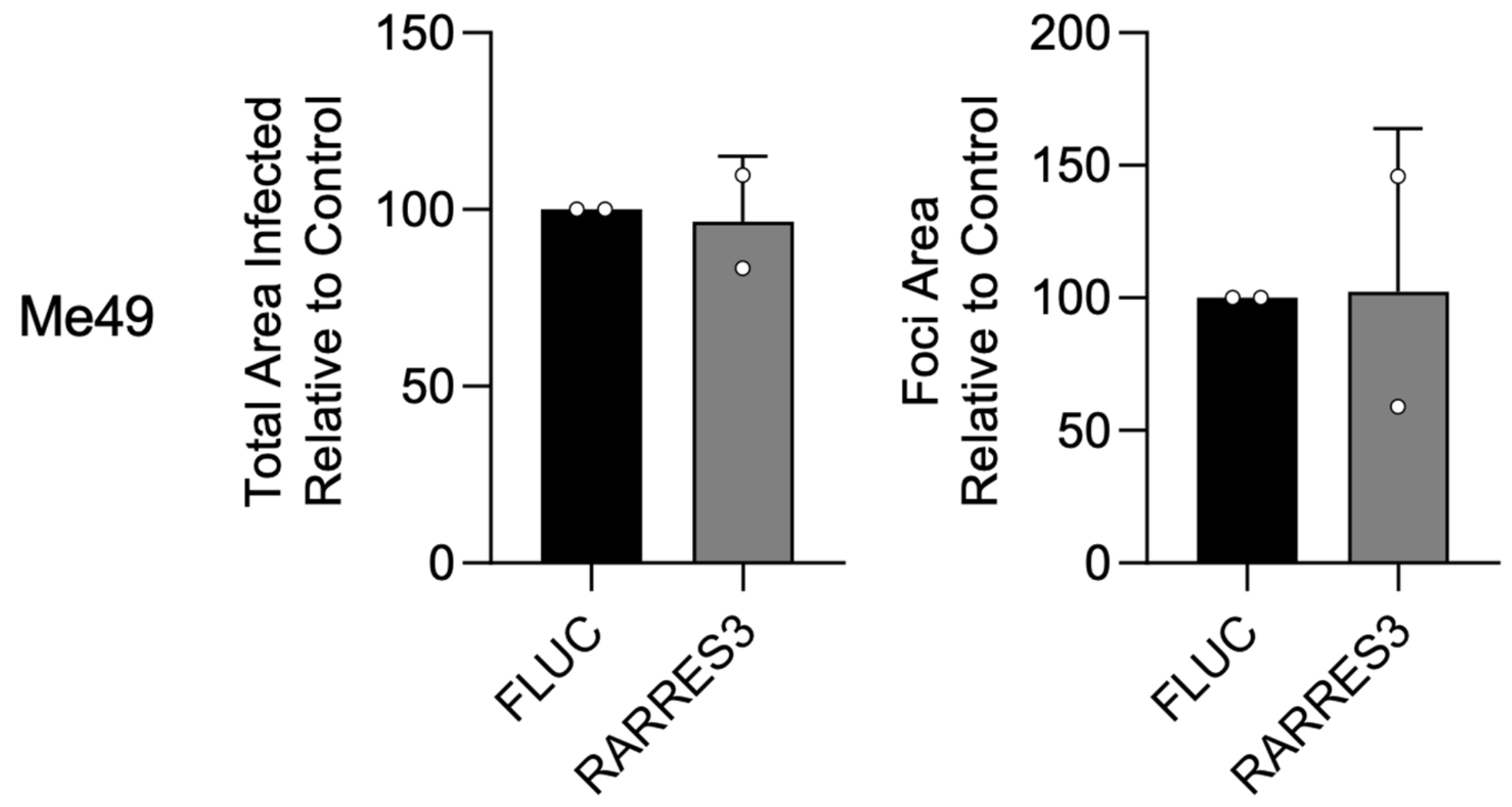


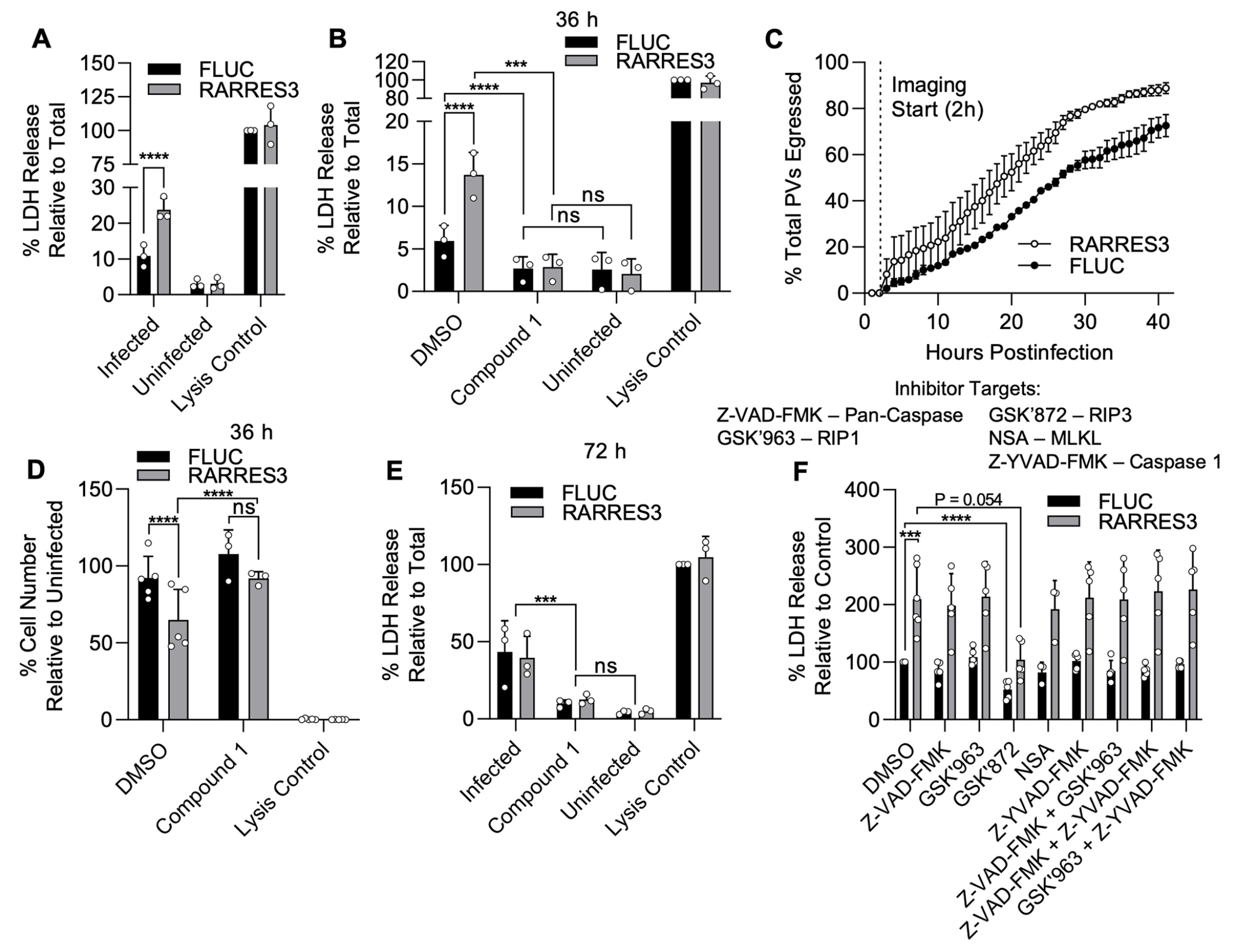


A

$36 \mathrm{~h}$

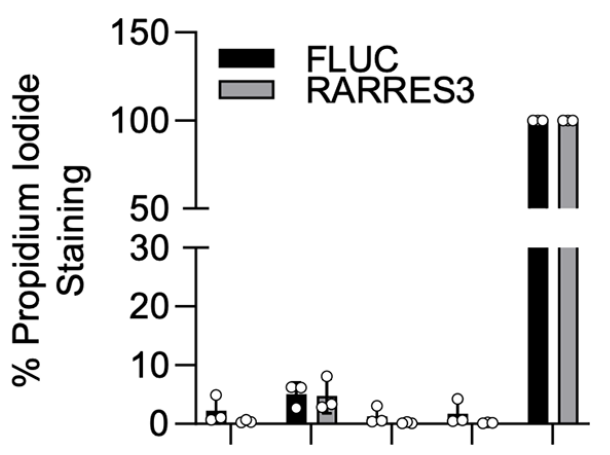

Compound 1 CTG-GFP

D

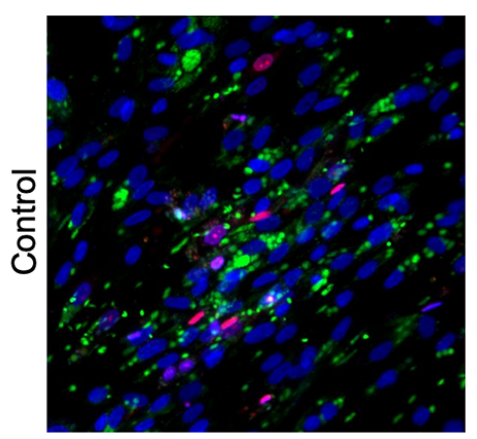

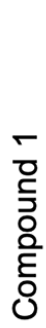

B

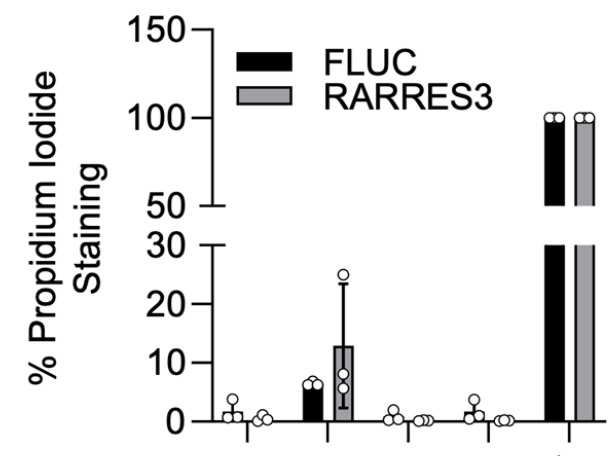

C

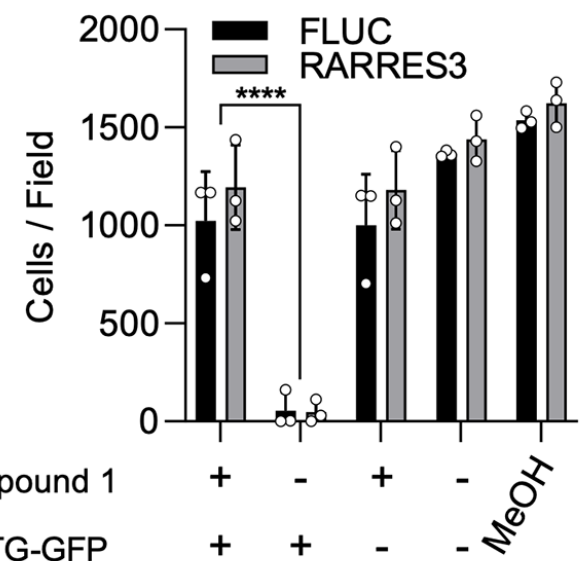

E

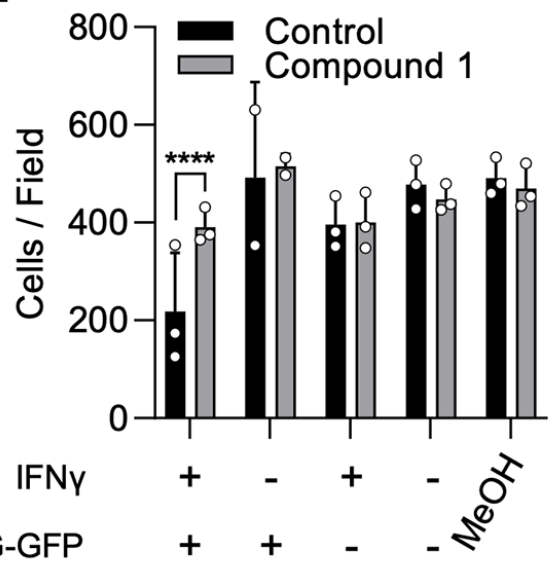

$F$

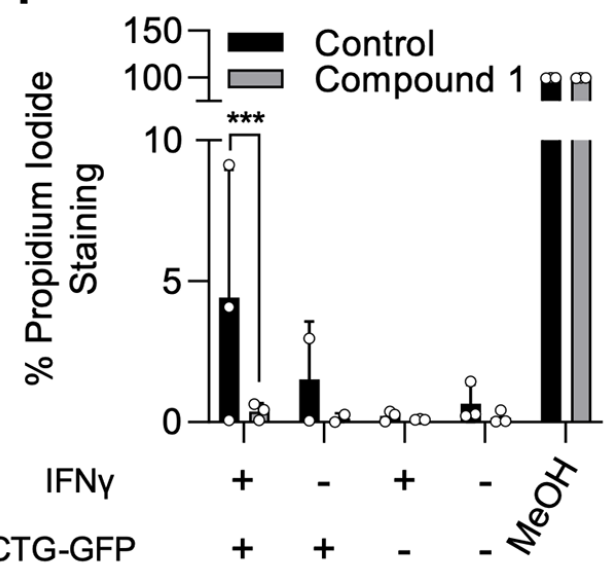




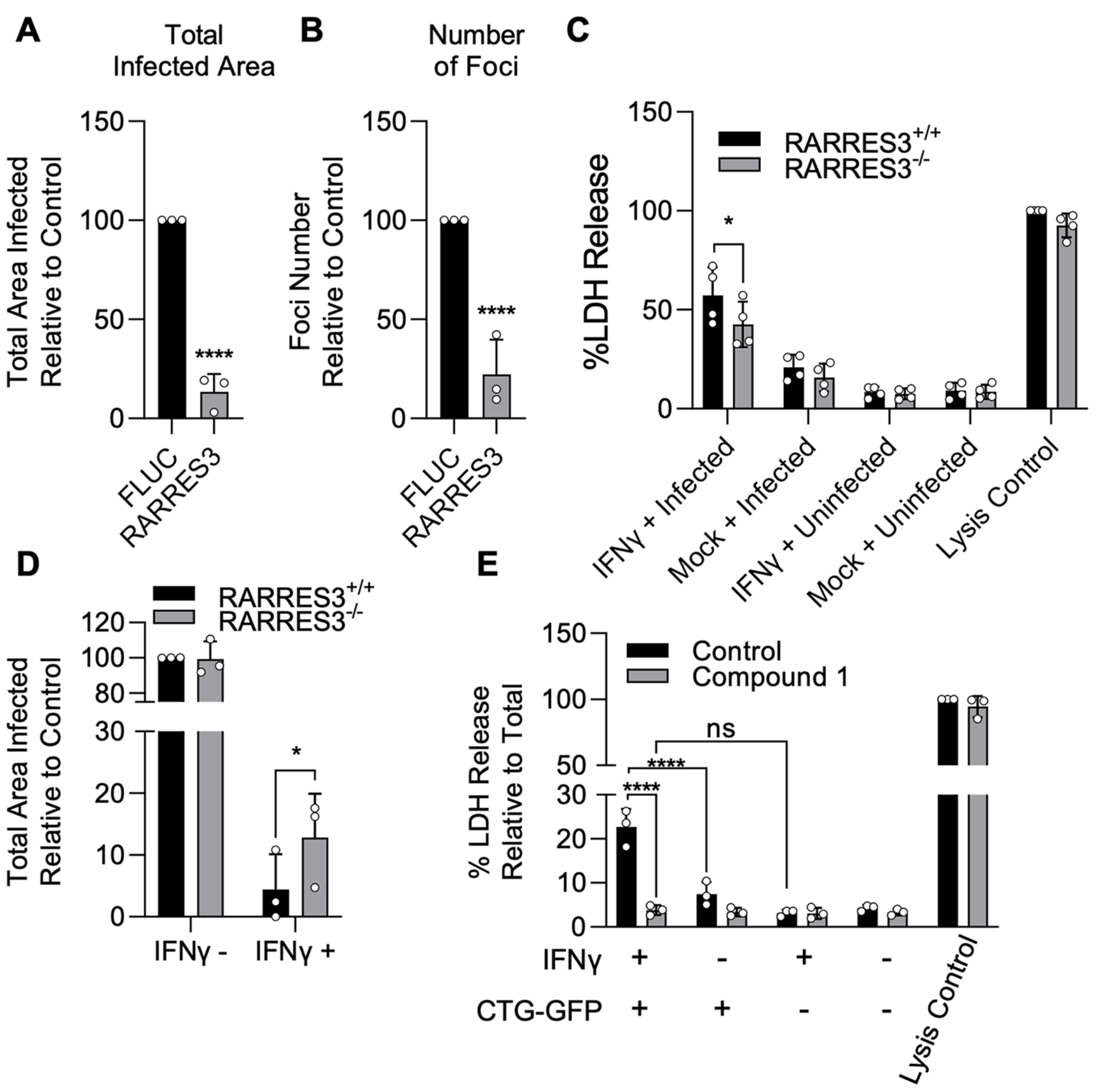

